\title{
The "Legal EPIDEMIOLOGY" OF THE TEEN SEXTING EPIDEMIC: HOW THE MEDIA INFLUENCED A LEGISLATIVE OUTBREAK
}

\author{
By Kimberlianne Podlas
}

Volume XII - Fall 2011

\begin{abstract}
This article considers the mediaes impact on the "legal epidemiology" of the teen sexting epidemic. Here, "teen sexting epidemic" refers to two things: (1) the belief that sext messaging by teens is rampant and spreading, hence, is an epidemic; and (2) the process by which a piece of information spreads like a virus, came to be understood as a pathogen infecting teens, resulted in a rash of child pornography prosecutions, and erupted into an outbreak of sexting legislation, hence, the epidemiology of the legal issue. This article argues that the media was both a carrier of this virus, in that it communicated the information and conceptual frameworks that formed the publices knowledge base of sexting and its legal implications, and a host environment in which forces interacted and transformed. To better understand the mediaes role, this article includes an empirical analysis of the past five years of media coverage of teen sexting, and identifying both its temporal and topical trends. With this quantitative and qualitative base, the article then analyzes the relationship between coverage and the progression of the teen sexting epidemic from a social issue to a legal issue and, ultimately, to an outbreak of "curative" legislation. In doing so, it focuses on the child pornography prosecutions of teen sexters, the media"s criticism of that course of action, the reincarnated stories of sext-related suicides, and the nation"s recent sext-related legislation.
\end{abstract}




\title{
The "Legal EPIDEMiology" OF THE TeEn SeXting EPIDEMIC: How THE Media INFLUENCED A Legislative OUTBREAK
}

\author{
By Kimberlianne Podlas ${ }^{\#}$
}

Volume XII - Fall 2011

\section{INTRODUCTION}

This article considers the media"s impact on the "legal epidemiology" of the teen sexting epidemic. It analyzes how media coverage helped teen sexting emerge as a public issue, nurtured its transformation into a legal issue, and influenced the recent outbreak of legislation intended to address it.

This article uses the phrase "teen sexting epidemic" ${ }^{1}$ in two ways. First, it uses it to refer to the commonly held belief that sext messaging by teens is rampant and spreading, hence, is an epidemic. Second, it uses the phrase to describe the process by which a piece of information spreads like a virus, came to be understood as a pathogen infecting teens, resulted in a rash of child pornography prosecutions, and erupted into an outbreak of sexting legislation, hence, the epidemiology of the legal issue.

Malcolm Gladwell inspired the concept of "legal epidemiology". Gladwell asserts the way ideas transform to produce social epidemics or change is analogous to the way viral agents produce biological epidemics. ${ }^{2}$ This article argues that, with regard to teen sexting, the media was both a carrier of the virus, in that it communicated the information and conceptual

\footnotetext{
\# Associate Professor of Media Law, University of North Carolina, Greensboro, Dept. of Media Studies; JD, cum laude, SUNY at Buffalo, School of Law; BA, magna cum laude, SUNY at Buffalo.

${ }^{1}$ Sexting was first reported and labeled by a British newspaper in 2005. See, e.g., Ben Fulton, Sexting: Inflated Issue or Menace? Salt LaKe Tribune, May 30, 2010.

2 Malcolm Gladwell, The Tipping Point 9-11 (2006); Carpenter has applied this idea to the emergence of legislative epidemics. See Catherine L. Carpenter, Legislative Epidemics: A Cautionary Tale of Criminal Laws that Have Swept the Country, 58 BufF. L. REV. 1, 1-2 (2010).
} 
frameworks that formed the public"s knowledge base about sexting and its legal implications, and a host environment in which forces interacted and transformed.

Indeed, by reporting news, as well as by choosing which news to report and how, the media plays an important role in the cultural production of knowledge. Media coverage can increase the potency of otherwise insignificant facts, portray courses of action as either illadvised or necessary, and establish frameworks for examining issues. Inasmuch as this forms the foundation from which people and policymakers assess issues and understand the application of law, media coverage impacts legal policy. ${ }^{3}$

To better understand the mediaes role in this process, this article includes an original empirical study of the media coverage of teen sexting as it relates to legal and legislative action. First, it compiles and calculates a baseline of media coverage of the issue over the last five years. Next, it identifies both temporal and topical trends of that coverage, and assesses its content to extrapolate dominant themes. With this quantitative and qualitative base, the article analyzes the relationship between coverage and the progression of the teen sexting epidemic from a social issue to a legal issue and, ultimately, to an outbreak of "curative" legislation. In doing so, this article focuses on the child pornography prosecutions of teen sexters, the media"s criticism of that course of action, the reincarnated stories of sext-related suicides, and the nation"s recent sext-related legislation.

\footnotetext{
${ }^{3}$ See Kimberlianne Podlas, Funny or No Laughing Matter?: How Television Viewers Interpret Satires of Legal Themes, 21 J. Seton Hall J. Sports \& Ent. L. 289, 290 (2011); Kimberlianne Podlas, The CSI Effect, Exposing the Media Myth, 16 FordHAM InTEll. Prop. Media \& ENT. L.J. 429, 443-44 (2006)(media plays a role in cultivating public opinion and constructing legal culture).
} 


\section{SEXTING}

In just a few years, sext messaging - sending a sexual photo or message by text ${ }^{4}-$ has become part of both American language and culture. ${ }^{5}$ It has also become the subject of considerable debate, ${ }^{6}$ widely criticized prosecutions, ${ }^{7}$ and a flurry of recent legislation. ${ }^{8}$

\section{STRAINS OF SEXTING}

Opinions about sext messaging vary, particularly whether it constitutes a problem warranting legal intervention. Often those opinions depend on whether sexting is between adults or adolescents. ${ }^{9}$

With regard to sext messaging by adults, some people think it is acceptable, ${ }^{10}$ others believe it is inappropriate or ill advised, but most agree that it is private. ${ }^{11}$ For the most part, the

\footnotetext{
${ }^{4}$ Logan v. Sycamore Community School BOE, 2011 U.S. Dist. LEXIS 10505 (S.D. Oh. 2011) at *3; NY TIMES, at 30; Meghaan C. McElroy, Sextual Frustrations: Why The Law Needs To Catch Up To Teenagers' Texts, 48 HoustON LAWYER 10, 13 (Nov. 2010)(sext messages can be comprised of words, images, or both, and run the gamut from tame to obscene); Kara Rowland, Sexting Is Thorny Legal Issue, WASHINGTON Times, June 23, 2009, at B 01.

${ }^{5}$ Fulton, supra note 1. The Oxford English Dictionary includes the word "sexting," and defines it as "the sending of sexually explicit texts and pictures by cell phone." Others define sexting as "sending pornographic text messages," Edward Mason, Teen Sext Flick Shocker, Boston Herald, Mar. 30, 2009, at 003, or sending nude and semi-nude photos via cell phone. See, e.g., Terri Day, The New Digital Dating Behavior - Sexting: Teens' Explicit Love Letters, Criminal Justice or Civil Liability, 33 Hastings Comm. \& EnT. L.J. 69, 70 (2010); Matt Friedman \& Megan DeMarco, Educating Teens On The Dangers Of Sexting Legislator Pushes Awareness As Alternative To Prosecution, StAR-Ledger (NJ), Jan. 25, 2011, at 007; Alexandra Marks, Charges Against Sexing Teenagers Highlight Legal Gaps, CHRISTIAN SCIENCE Monitor, Mar. 31, 2009, at 25.

${ }^{6}$ Susan Hanley Duncan, A Legal Response Is Necessary for Self-Produced Child Pornography: A Legislator's Checklist for Drafting the Bill, 89 OR. L. REV. 645, 649-50 (2010).

${ }^{7}$ See, e.g., Editorial, Prosecutors Gone Wild, NY York Times, Mar. 25, 2010, at 30 (asserting that this issue should be handled by parents, not schools or prosecutors) [hereinafter Prosecutors Gone Wild]; Dan Casey, Being Young is Not a Felony, RoANOKE Times (VA), May 23, 2010, at B1 (issue for parents, not prosecutors); Suzanne Fields, Teen Sexting: In Nä̈ve Hands, Cell Phones Can Ruin Lives, Washington Times, Mar. 31, 2011, at Sec. B (describing prosecutions as overzealous); Monica Yant Kinney, No Need To Go Overboard On Teens' Sexting, Philadelphia Inquirer, Feb. 6, 2011, at B01 (asserting that it is a parent"s decision as to how to treat or address sexting); Errol Louis, Sexting Spawns Witch Hunt, DAILY News (NY), Apr. 23, 2009, at 31 (likening sexting prosecutions to the 1692 Massachusetts witchcraft trials); Dan Rubin, Proposed Sexting Law Could Do More Harm Than Good, PhiladelPhia InQuirer, Aug. 5, 2010, at B 01 (criticizing prosecutions).

${ }^{8}$ See notes 247-257, infra.

${ }^{9}$ Catherine Arcabascio, Sexting and Teenagers: OMG R U Going 2 Jail???, XVI Rich. J.L. \& TECH. 9 (2010) (adults sext but most concern is about teens).

10 Fields, supra note 7, at Sec. B (adult sexting advocated as way to improve sex life); Jan Hoffman, A Girl's Nude Photo, and Altered Lives, NEW YORK TIMES, Mar. 27, 2011, at A 1 (adult sexting is permissible party of adulthood; senior sexting encouraged by AARP); Rich Schapiro, Sexting's Rampant in Culture. Just Teens? Think Again! DAILY News (NY), June 19, 2011, at 18; Shannon Shafron-Perez, Average Teenager Or Sex Offender? Solutions To The Legal Dilemma Caused By Sexting, 26 J. Marshall J. Computer \& INFO. L. 431, 431-32 (2009) (touted by mass media as means to improve intimacy in relationships); Lawrence G. Walters, Symposium: Sexually Explicit Speech: How To Fix The Sexting Problem: An Analysis Of The Legal And Policy Considerations For Sexting Legislation, 9 FIRST AMEND. L. REV. 98, 99-100 (2010) (behavior is perfectly
} 


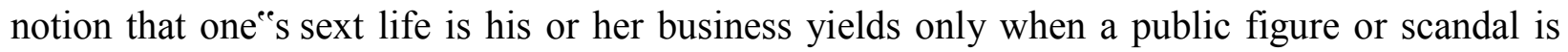
involved. $^{12}$

With regard to sext messaging by teens, opinions are more diverse and more polarized. Because teen sexting raises complex cultural issues ${ }^{13}$ and disconcerting questions of emerging sexuality, ${ }^{14}$ it is treated as a matter of public concern.

People disapprove of teen sexting for a number of reasons. ${ }^{15}$ Some simply believe that it is immoral ${ }^{16}$ or perverse, ${ }^{17}$ and adolescent sexuality should not be encouraged. Others fear the harm to a teen should a sext spread publicly. ${ }^{18}$ Still others insist that this is not a matter of personal opinion but of law. For instance, several prosecutors have equated sexting with child pornography ${ }^{19}$ and prosecuted teens for sending or receiving sext messages. Similarly, a number of lawmakers have sought to punish or regulate it in some way. ${ }^{20}$ Even the popular press

legal among adults). Jessica Leshnoff, $C^{*} U^{*} 2$ nite: Sexting Not Just for Kids, AARP, Nov. 2009, http://www.aarp.org/relationships/love-sex/info-11-2009/sexting_not_just_for_kids.html (AARP (formerly The American Association of Retired Persons) has reported, with approval, that seniors are sexting too).

${ }^{11}$ Shafron-Perez, supra note 10, at 432; Judith Timson, Sex, Sex, Sex. We're Trapped In Sex-Scandal Hell, Globe \& MaIL (CANADA), Apr. 9, 2010, at L1 (private sexual betrayal); Cosmopolitan.com, The Sex Toy Hiding in Your Purse (2009) $\mathrm{http}: / / \mathrm{www} . c 0 s m o p o l i t a n$. com/sex-love/tips-moves/The-Sex-Toy-Hiding-in-Your-Purse. In fact, to help sexts stay private, there is now an iPhone app called "TigerText" that causes sexts to self-delete from the sender and user"s phones. Mark Lelinwalla \& Ebenezer Samuel, Not So Fast All You Sexters!, DAILy News, Mar. 7, 2010, at 67.

12 Timson, supra note 11.

${ }^{13}$ Shafron-Perez, supra note 10 , at 433.

${ }^{14}$ Fulton, supra note 1.

${ }^{15}$ Friedman \& DeMarco, supra note 5, at 25; McElroy, supra note 4, at 10, 16; Claudia Feldman, Message Is Out On Sexting. Teens Learning Consequences Of Texting Nudity Sexting: Teenagers Aren't Aware Of The Potential Consequences, Houston Chron., Apr. 5, 2009, at 1; Tamara Lewin, Rethinking Sex Offender Law for Youth Texting, NY TimeS, Mar. 20, 2010, available at http://www.nytimes.com/2010/03/21/us/21sexting.html; Megan Sherman, Sixteen, Sexting, And A Sex Offender: How Advances In Cell Phone Technology Have Led To Teenage Sex Offenders, 17 B.U. J. SCI. \& TECH. L. 138, 147 (2011).

${ }^{16}$ Day, supra note at 5, 71-72; Michael W. Macleod-Ball, Symposium: Youth and Social Media: Student Speech Online: Too Young to Exercise the Right to Free Speech? 7 I/S J.L. \& POL"Y FOR INFO. SOC'Y 101, 129 (2011).

${ }^{17}$ See Claudio J. Pavia, Constitutional Protection of "Sexting" in the Wake of Lawrence: The Rights of Parents and Privacy, 16 VA. J.L. \& TECH. 189, 194 (2011).

${ }^{18}$ Fulton, supra note 1; Leslie Parrilla, Four Teens Cited in Sexting Case, The Press EnTERPrise (Riverside, CA), Apr. 15, 2010, at A1; but see A.H. v. State, 949 So. 2d 234, 239 (Padovano, J., dissenting) (describing the risk of potential disclosure as speculative).

19 Emily Bazelon, How Not To Prosecute a Sexting Case, Slate Magazine, (Mar. 18, 2010) http://www.slate.com/articles/life/bulle/2010/03/how_not_to_prosecute_a_sexting_case.2.html; Fulton, supra note 1; Parrilla, supra note 18, at A1; Jeremy Pawloski, Three Lacy Teens Face Felony Sexting Charges, NeWs TriBUNE (WA), Jan. 30, 2010, at A 004; Stephen Treglia, Symposium Presentation: The Clash of Titanic Paradigms - The American Criminal Justice System Versus Modern Computer Technology, 20 ALB. L. J. SCI. \& TECH. 407, 411-12 (2010) (but also noting that prosecution is a policy decision).

${ }^{20}$ Fulton, supra note 1; Tom Joyce, ACLU Objects to Grove's Sexting Proposal, EvenING Sun (PA), (Feb. 8, 2010), available at http://www.allbusiness.com/government/government-bodies-offices-regional/13892175-1.html. Indeed, as new modes of digital 
declared, "Most scholars agree sexting is wrong and teenagers engaged in this type of behavior should be punished." 21

By contrast, many young adults see nothing wrong with sexting. ${ }^{22}$ To them, it is simply another way to flirt, ${ }^{23}$ cultivate romance, or express their sexuality. ${ }^{24}$ In fact, sexting is tamer than many sexual activities ${ }^{25}$ and cannot result in pregnancy or an STD. ${ }^{26}$ Other people, including various researchers, describe sexting as a normal, albeit digital, ${ }^{27}$ component of a sexual relationship, ${ }^{28}$ likening it to other adolescent explorations ${ }^{29}$ of sexuality. ${ }^{30}$ In the words of

interaction have emerged, from video games, to the Internet, to social networking sites, so have legislative attempts to suppress them as harmful to youth or as contributing to a perceived moral decline of the nation. Macleod-Ball, supra note 16; Sherman, supra note 16 , at 108 .

${ }^{21}$ Lewin, supra note 15 (quoting professor Amy Adler); McElroy, supra note 4, at 10, 16 (sexting "must be addressed, monitored, and curtailed); Parrilla, supra note 18, at A1 (sexting poses legal and ethical concerns). This article questions the assertion that a majority of scholars believe that sexting warrants punishment. Though some authors may believe that sexting is problematic and deserves legal attention, others may simply be repeating this conventional wisdom, or be reluctant to dispute the conventional wisdom in the public forum of a law review or newspaper article.

${ }^{22}$ What They're Saying About Sexting, NY TIMES, Mar. 27, 2011, at A 20. This does not mean that all teens think that it should be practiced. Id. Nonetheless, teens who criticize sexting and decry it as a means of harassment seldom advocate its criminal regulation. See also, 'Sexting' Fad Has Gone Too Far, Teen Says, Toronto Star, June 2, 2010, at A22.

${ }^{23}$ See, e.g., Weronika Kowalczyk, Abridging Constitutional Rights: Sexting Legislation in Ohio, 58 CLEV. ST. L. REV. 685,691 (2010); Sarah Wastler, Student Article: The Harm In "Sexting"?: Analyzing The Constitutionality Of Child Pornography Statutes That Prohibit The Voluntary Production, Possession, And Dissemination Of Sexually Explicit Images By Teenagers, 33 HARV. J.L. \& GENDER 687, 691 (2010) (describing post-modern flirting); Phil Kloer \& Helena Oliviero, Cover Story: Teens' Internet Safety, Atlanta Journal-Const., Feb. 15, 2009, at 1G; Friedman \& DeMarco, supra note 5, at 007; Sherman, supra note 14, at 142.

${ }^{24}$ Amanda M. Hiffa, Omg Txt Pix Plz: The Phenomenon Of Sexting And The Constitutional Battle Of Protecting Minors From Their Own Devices, 61 Syracuse L. Rev. 499, 504 (2011); What They're Saying About Sexting, NY TimeS, Mar. 27, 2011, at A 20 (teen describing it as a way of saying you are in love); Kloer \& Oliviero, supra note 23, at $1 \mathrm{G}$ (describing it as a means to gain attention or complying with a boy's request).. Some authors report that most sexting involves girls sending photos of themselves to boys. See, e.g., Kloer \& Oliviero, supra note 23; see also Fields, supra note 7, at Sec. B (noting double standard regarding girls and boys sexting).

${ }^{25}$ Kowalczyk, supra note 23, at 691. See also Michael K. Curtis \& Shannon Gilbreath, Transforming Teenagers Into Oral Sex Felons: The Persistence of the Crime Against Nature After Lawrence v. Texas, 43 WAKE FOREST L. REV. 155, 215-16 (2008) (explaining that teen sexual activity is more common than judges acknowledge).

${ }^{26}$ What They're Saying, supra note 24, at A 20. The New York Times conducted individual, structured interviews of two groups of teenagers.

${ }^{27}$ Macleod-Ball, supra note 16, at 103.

${ }^{28}$ Clay Calvert, Sex, Cell Phones, Privacy, And The First Amendment: When Children Become Child Pornographers And The Lolita Effect Undermines The Law, 18 CommLaw Conspectus 1, 13, 20 (2009); See also Feldman, supra note 15, at 1; Fulton, supra note 1 (sexting often occurs at the beginning of relationship); Kloer \& Oliviero, supra note 23, at 1G; Kowalczyk, supra note 23, at 691 (describing relationship contexts of sexting); Wastler, supra note 23, at 101 (describing sexting as selfexploration); Sherman, supra note 14, at 142.

${ }^{29}$ Researcher Nina Funnell says sexting is relatively common among 15 to 18 -year-olds, and they say that "it's about flirtation and pleasure and exploring their sexuality." Karen Brooks, Twits Like Weiner a Lesson for Us All, COURIER MAIL (Australia), June 15, 2011, at 32; See also Calvert, supra note 28, at 14.

${ }^{30}$ See John Palfrey, Essays From Time Warner Cable's Research Program On Digital Communications: The Challenge Of Developing Effective Public Policy On The Use Of Social Media By Youth, 63 Fed. ComM. L.J. 5, 6 (2010) (social norms in digitally mediated environments are extremely powerful); Martha Irvine, Parent Alert: 'Sexting' is Alarming Teen Trend, Deseret News (Salt Lake City, Utah), Feb. 8, 2009, at A1; Calvert, supra note 28, at 20. Senior Researcher with the Pew Internet and 
one psychologist, "We would have done it, too, if we would have had the cool phones."31 With regard to the legal implications, a number of scholars argue that because teen "auto-porn" does not share the unique circumstances of production, the underlying criminal act, and the potential harms of child pornography, sexting does not constitute child pornography. ${ }^{32}$

\section{SYMPTOMS OF TECHNOLOGY ANXIETY}

Whether one believes that teen sexting is digital herpes with lifelong consequences, a crime requiring punishment, or an issue blown out of proportion, sexting is about more than the intersection of technology and adolescent sexuality. Debate about sexting also manifests a broader cultural anxiety about technology and the blurring of the traditional lines between public and private.

Whereas adults embrace technology as a means to facilitate communication and information sharing, ${ }^{33}$ adolescents experience it differently. For adolescents, the digital world is not a mere communication medium ${ }^{34}$ or virtual adjunct to real life, but an important part of society in its own right. ${ }^{35}$ Growing up in that world ${ }^{36}$ changed how teens interact socially ${ }^{37}$ and romantically. $^{38}$

\footnotetext{
American Life Project Amanda Lenhart explains, "this is merely another case of technology extending an activity or action that young people have engaged in for years. Irvine, supra, at A1.

${ }_{31}$ Calvert, supra note 28, at 20 (citing to Paula Reed Ward, DA's Case Over Teen 'Sexting' Draws Ire of Parents, PITt. PostGAZETTE, Mar. 26, 2009, at A-1, available at 2009 WLNR 5651200); cf. Pavia, supra note 17, at 12 (opinion that argument rests on the outdated assumption that teenage sexting is "perverse").

32 See Calvert, supra note 28, at 45-47; Day, supra note 4, at 85-86. See also John A. Humbach, 'Sexting' and the First Amendment, 37 Hastings Const. L.Q. 433, 464-67 (2010); Kowalczyk, supra note 23, at 703-06; Macleod-Ball, supra note 16, at 117-118; Wastler, supra note 23, at 115.

${ }^{33}$ See Chang-Hoan Cho \& Hongsik John Cheon, Children's Exposure to Negative Internet Content: Effects of Family Context, 49 J. BroadCAsting \& Electronic Media 488, 501 (2005); Hiffa, supra note 24, at 504 (describing adult and business use of texts).

34 See Paul Haridakis \& Gary Hanson, Social Interaction and Co-Viewing With YouTube: Blending Mass Communication Reception and Social Connection, 53 J. Broadcasting \& Electronic Media 317, 319 (2009) (the Internet is both an interpersonal and mass communication medium).

${ }^{35}$ See Calvert, supra note 28, at 16-19; See also Chang-Hoan \& Hongsik, supra note 33, at 488; Charlotte Chang, Internet Safety Survey: Who Will Protect the Children, 25 BERKELEY TECH. L.J. 501-02 (2010) (statistics of use), 503-05 (popularity of social networking sites); Elizabeth C. Eraker, Stemming Sexting: Sensible Approaches to Teenagers' Exchange of Self-Produced Pornography, 25 BeRKeley TeCH. L.J. 555, 560-61 (2010).
} 
The cell phone has been one of these agents of change. Cell phones cultivated a new means of social interaction among teens founded on text messaging. ${ }^{39}$ Indeed, cell phones are no longer a mark of status, but a ubiquitous accessory, if not necessity, of the digital generation. ${ }^{40}$ According to a 2009 survey, eighty-three percent of thirteen to seventeen year-olds own a cell phone. $^{41}$ In fact, adolescents have evidenced their mastery of and status in this forum by developing our texting language of symbols and abbreviations. ${ }^{42}$ Not surprisingly, some teens are more comfortable communicating and establishing an identity in this forum than in traditional ones. $^{43}$

This has fostered new norms ${ }^{44}$ and understandings of "personal" and "private.",45 Moreover, having emerged alongside the norms of the "real" world, the norms of the digital

\footnotetext{
${ }^{36}$ See Palfrey, supra note 29, at 13-15 (adolescents have always lived in a world with the Internet); See also Charlotte Chang, supra note 35, at 501 (many children are introduced to the Internet and digital culture as toddlers sitting on their parents laps).

${ }^{37}$ Haridakis \& Hanson, supra note 34, at 320 (researchers have devoted a significant amount of attention to the interaction between digital media use and offline social interaction. Some studies suggest that greater Internet use results in smaller social circles, whereas other research suggests that greater Internet use results in wider social circles).

${ }^{38}$ See Charlotte Chang, supra note 35, at 502; Eraker, supra note 35, at 557-58. See also Sherman, supra note 13, at 139 (new form of social interaction); Arcabascio, supra note 9, at par. 8 (computers and cell phones have altered the way that people interact).

${ }^{39}$ See Arcabascio, supra note 9, at par. 9; Calvert, supra note 28, at 16. See also Amanda Lenhart, et al., Pew Internet \& American Life Project (Pew Research Center),Teens and Sexting, Dec. 15, 2009, at 2; Amanda Lenhart, Teens and Mobile Phones, Apr. 20, 2010, available at http://www.pewInternet.org/Reports/2010/Teens-and-Mobile-Phones/Summary-offindings.aspx; Sherman, supra note 13, at 140. For an explanation of how Multimedia Messaging Service, MMS, allows cell phone users to send texts, photos, and videos to other MMS-compatible phones, see Sherman, supra note 13, at 140-41.

40 Laura Petrecca, Cell Phone Marketers Calling All Preteens, USA ToDAY,(Sept. 5, 2005, 7:29 PM), http://www.usatoday.com/tech/products/gear/2005-09-05-preteen-cell-phones_x.htm. Approximately 66\% of teens own a cell phone before the age of 14 , and almost $75 \%$ of high school students have cell phones. Lenhart, Teens and Mobile Phones at 9. Twenty-three percent of teenagers 12-17 years old who own cell phones use them to access social networking sites. Id. at 56; J.S. v. Snyder, 2011 U.S. App. LEXIS 11947 at *97 (3d Cir. 2011) (dissent); Joseph O. Oluwole \& William Visotsky, The Faces Of Student Cell Phone Regulations and The Implications Of Three Clauses Of The Federal Constitution, 9 CARDOZO PUB. L. POL'Y \& ETHICS J. 51 (2010) (rise in popularity of cell phones among students); Petrecca, supra note 40 (sixteen million children have cell phones). The MTV and Associated Press survey found that $81 \%$ of respondents had cell phones with cameras. Knowledge Networks, The Associated Press-Mtv Poll Digital Abuse Survey Conducted By Knowledge Networks 2 (2009), available at http://surveys.ap.org/data/KnowledgeNetworks/AP_Digital_Abuse_Topline_092209.pdf.

${ }^{41}$ Lenhart, supra note 39 , at 2.

${ }^{42}$ Hiffa, supra note 24, at 503-04. Some parents and educators, however, assert that the digital generation "es proficiency in communicating in digital social forums impedes their development of social interaction skills in the real world. Cho \& Cheon, supra note 33 , at 490 .

43 Arcabascio, supra note 9, at par 9-10. For teens, the portability and ability to communicate without others having contemporaneous knowledge of what is being said enhances the cell phone 16-17; see also Day, supra note 5 at 70 (noting that adolescents embrace and expect the instantaneous connectivity provided by cell phones).

${ }^{44}$ Eraker, supra note 35, at 557-58; Fields, supra note 7, at Sec. B; Palfrey, supra note 30, at 6, 13-15 ("Social norms in digitally mediated environments are extremely powerful."). For a definition of social norms and their relationship to actions, see
} 
world inform the norms of youth culture generally. ${ }^{46}$ Because teens have been reared in a culture that embraces exhibitionism ${ }^{47}$ and forges meta-celebrity ${ }^{48}$ via mass media, ${ }^{49}$ disclosing personal information, ${ }^{50}$ sharing self-created media ${ }^{51}$ with a vast number of people, ${ }^{52}$ and inviting public commentary on one ${ }^{e e}$ s personal life, ${ }^{53}$ are considered normal. As a result, teens ${ }^{e e}$ notions of privacy differ from earlier generations. ${ }^{54}$ For example, teens share more personal information within their digital cohort, but also take steps to keep it private from parents and teachers. ${ }^{55}$ Thus, they do not necessarily equate this managed disclosure with extinguishing their privacy. ${ }^{56}$ This blurs the traditional borders of private and public ${ }^{57}$ and reconceptualizes what privacy means. $^{58}$

Teen sexting reflects this changing normative territory and literally embodies its risks. ${ }^{59}$ On this adjusted normative backdrop, a cell phone in the hands of an adolescent can be

Kimberlianne Podlas, As Seen on TV: The Normative Influence of Syndi-court on Contemporary Litigiousness, 11 VILL. SPORTS \& ENT. L. J. 1, 16-17, 19 (2004).

${ }^{45}$ Calvert, supra note 28, at 18-19; Palfrey, supra note 30, at 9, 13-15.

${ }^{46}$ Chang-Hoan \& Hongsik, supra note 33, at 488-89 (noting internet is a powerful agent of socialization for youth); Kinney, supra note 7 (cultural norm of oversharing). In other words, whereas adults may consider the real-world and the digital world to be separate spheres regulated by different norms, youth culture does not perceive these worlds as separate spheres, but as coequal components of culture. Hence, they are governed by similar, rather than separate, norms.

${ }^{47}$ Calvert, supra note 28, at 17; Haridakis \& Hanson, supra note 34, at 317-18 (describing sharing and critique aspects of social network sites and YouTube); Hiffa, supra note 23, at 504 (noting convergence of technology with narcissism); Kinney, supra note 7, at B01 (describing the contemporary culture of oversharing); Michael Steffanone et al., The Relationship Between Traditional Mass Media And "Social Media": Reality Television As A Model For Social Network Site Behavior, 54 J. BROAdCASTING \& ElECTRONIC MEDIA 508, 513 (2010).

48 Steffanone, supra note 47, at 509-12, 514 (explaining youth engagement with "social" technology).

${ }^{49}$ No longer is a narcissist just a legend in her own mind, but can be digitally enhanced to become a celebrity on her own Facebook page.

${ }^{50}$ Haridakis \& Hanson, supra note 34, at 317-18; Kinney, supra note 7, at B01.

${ }^{51}$ This includes blogs, photos, and videos. Steffanone, supra note 47, at 511.

${ }^{52}$ See Calvert, supra note 28, at 17-20 (contrasting differences between teen and adult perceptions of sharing information via digital means); Steffanone, supra note 47, at 511 (noting differences in teen sharing behaviors and perceptions).

${ }^{53}$ See Calvert, supra note 28, at 17-21; Chang, supra note 35, at 503; see also Eraker, supra note 35, at 560-62 (discussing teen texting and Internet-oriented behaviors); Steffanone, supra note 47, at 511 (explaining youth engagement with "social" technology).

${ }^{54}$ Calvert, supra note 28, at 18-19; Palfrey, supra note 30, at 13-15 at 9.

${ }^{55}$ Palfrey, supra note 30, at 8-9, 13-15. The information teens choose to share digitally (as on a social networking site) or to hide is part of the process of defining identity. $I d$. at 13.

${ }^{56}$ Palfrey, supra note 30 , at 13-15, at 8-9.

${ }^{57}$ See Fields, supra note 7, at Sec. B.

${ }^{58}$ Calvert, supra note 28, at 18-19 (what adults might consider private, teens may not); See Fields, supra note 7, at Sec. B (discussing changes in teen norms); Steffanone, supra note 47, at 510-12 (differences in conceptions of privacy).

${ }^{59}$ Editorial, A Youthful Mistake Shouldn't Be A Felony, St. Petersburg Times (FL), May 1, 2011, at 2P [hereinafter Youthful Mistake] (asserting that "it is important to deliver a message to a generation raised on technology and surrounded by sexually 
dangerous. ${ }^{60}$ Teens are afflicted with the impulsivity of youth: ${ }^{61}$ they may be smart, but they do not always make smart choices. Research demonstrates that while adolescents may possess significant intellectual capabilities, their prefrontal cortexes are not yet fully developed. ${ }^{62}$ Consequently, they do not possess the cognitive ability to appreciate fully the long-term consequences of their behavior. ${ }^{63}$ In addition, they lack the control to keep their impulses in check. $^{64}$ The result can be texting without reflection. ${ }^{65}$ Thus, the technology that empowers teens also enables them to be the masters of their own humiliation. ${ }^{66}$

\section{THE ETIOLOGY OF TEEN SEXTING}

To the extent that there is any consensus that teen sexting poses a problem, there is no consensus regarding what the actual problem is. Rather, it can be conceptualized in many ways: Is teen sexting symptomatic of hyper-sexualized adolescents or culture ${ }^{\text {ee }}$ moral rot? Does the distribution of a sext pose such a potential for long-term harm as to warrant regulation? Does sext legislation unconstitutionally criminalize protected sexual speech? Is this a privacy or

charged media that the most damning consequence of sexting is the permanent invasion of a youth's privacy and the lasting embarrassment").

${ }^{60}$ Day, supra note 5, at 70; See Fields, supra note 7, at Sec. B; See (Jan) Hoffman, supra note 10.

${ }^{61}$ Jeffrey Arnett, Reckless Behavior in Adolescence: A Developmental Perspective, 12 Developmental Rev. 339,339 (1992) ("[A]dolescents are overrepresented statistically in virtually every category of reckless behavior.").

${ }^{62}$ Kristen Burillo, Less Capable Brain, Less Culpable Teen? The Civic Column, Report From The Mercyhurst College Civic Institute (Sep. 2010), available at http://www.civicinstitute.org/wordpress/wp-content/uploads/2010/09/Civic-Column-Fall2010.pdf; Ken C. Winters, Adolescent Brain Development And Drug Abuse (2008), available at http://www.tresearch.org/adolescents/NewTeenBrainWriteup.pdf..

${ }^{63}$ Parrilla, supra note 18, at A1; See also Jordan J. Szymialis, Sexting: A Response to Prosecuting Those Growing Up with a Growing Trend, 44 IND. L. REV. 301, 305-07 (2010). Teens are also easily influenced by their environment. Debra Bradley Ruder, The Teen Brain: A Work in Progress, HARv. MAG., Sept.-Oct. 2008, at 8, available at http://harvardmag.com/pdf/2008/09-pdfs/0908-8.pdf.

${ }^{64}$ See Burillo, supra note 62; Winters, supra note 62 (they do not yet posses a fully-developed (prefrontal cortex or the cognitive ability to keep impulses in check). In Roper v. Simmons, the Supreme Court acknowledged the "impetuous and ill-considered actions and decisions" of adolescents. 543 U.S. 551, 569 (2005)(quoting Johnson v. Texas, 509 U.S. 350, 367 (1993)).

${ }^{65}$ See Fulton, supra note 1; See Arcabascio, supra note 9, at 9ף 9-10. Cell phones so significantly reduce the time between thought and action that they eliminate time for reflection, and teens are already somewhat disabled when it comes to reflection. Indeed, the ability of cell phones to take, send, and receive photographs helped generate the sexting trend, in the first place. Cassell Bryan-Low \& David Pringle, Sex Cells: Cell Phone Operators Find that Sex Sells Broadband, Wall St. J., May 12, 2005, at B1; See also McElroy, supra note 4, at 11; See also Sherman, supra note 15, at 141.

${ }^{66}$ Hiffa, supra note 24, at 504. 
parenting issue outside of the purview of government? Is this an overreaction of policymakers or self-designated moral arbiters of behavior $?^{67}$

Typically, such fractured opinions would not provide a sufficient foundation for the type of swift, significant legal and legislative actions that have occurred in response to teen sexting. Nonetheless, in less than three years, the teen sexting epidemic has metastasized into public consciousness, led to a wave of prosecutions intended to stop its spread, and an outbreak of curative legislation.

This article asserts that the media is a key factor in this legal epidemiology. By opting to cover certain topics, determining their prominence, and choosing how to portray them, the media does more than disseminate information: it participates in the cultural production of knowledge and influences perceptions. ${ }^{68}$ This foundation can influence what the public and lawmakers believe is an issue warranting legal intervention and provide an impetus for such action. In the case of teen sexting, the media spread the "virus" or ideas about sexting and served as a host environment nurturing the issue and enabling it to emulsify with other factors to become a more virulent social issue. Ultimately, this influenced the legal systemes response and the focus of recent sexting legislation.

\section{EMPIRICAL STUDY}

To better appreciate (and substantiate) the relationship between the media and the legal epidemiology of the issue, an original empirical study of the media coverage of teen sexting was conducted. This study measured and evaluated media coverage (including its amount, emphasis, trends, themes, and slant) of teen sexting and related topics, and linked it to critical points in the

\footnotetext{
${ }^{67}$ Macleod-Ball, supra note 16, at 120.

${ }^{68}$ Podlas, supra note 44, at 10-11.
} 
progression of legal and legislative responses. To that end, the study includes quantitative and qualitative components.

The study used the LEXIS database to obtain all (LEXIS) media coverage of teen sexting from $2006^{69}$ through June $2011 .^{70}$ Although this does not encompass the universe of all sexting coverage from every media source, it comprises a relatively representative sample of coverage from which proportions can be calculated and trends can be observed. Once data was obtained from the "ALLNEWS" database, ${ }^{71}$ it was cross-referenced against each subgroup "ALLNEWS." The same protocol was repeated to compile data on sexting legislation, sexting-related suicides, and criminal prosecutions of teen sexters.

Duplicate coverage listings, ${ }^{72}$ press releases (and equivalent documents), articles in international press, ${ }^{73}$ and those that did not pertain to teen sexting were excluded from the final analysis. Once that coverage (herein, "coverage" or "stories") was compiled, the respective amount(s) of coverage were calculated. This is shown in Charts I and II. ${ }^{74}$

Next, the qualitative content of this coverage was reviewed in order to extrapolate the primary topics mentioned in coverage. ${ }^{75}$ The qualitative and quantitative results were then integrated and plotted in a timeline to show the progression of media coverage of events salient

\footnotetext{
${ }^{69}$ This marks the emergence of the term sexting.

${ }^{70}$ The search terms used to compile media coverage of sexting included: "sext," "sexting," and variants; "text," "texting," and variants; "cell" (and variants), "phone" and "photo" or "picture." These were searched in various combinations and proximities.

71 "ALLNEWS" served as the primary database and instrument of measurement.

72 Articles that were listed multiple times, but appeared once in a single media source were excluded. Articles that were syndicated, but appeared in separate media sources were not excluded. For example, a single article appearing in The New York Times on 11/11/2011 could have two separate LEXIS listings, because it ran in the East Coast edition and the West Coast edition. Therefore, this study excluded one. By contrast, an article that was syndicated and ran (and therefore listed in LEXIS) in both the Buffalo News and the San Francisco Chronicle was not excluded, because it was in two different media sources (thereby transmitting information to two different audiences).

${ }^{73}$ Because this article proposes that the American media impacted the American public and legal system"s response to teen sexting, articles appearing in international media were excluded.

${ }^{74}$ Coverage is divided as to whether it occurred before or after October 2009, the date of the Cosmogirl Survey (see infra and note 90). This survey was the first to assert that teen sexting was prevalent, and, hence, is the first viral agent in what became the teen sexting epidemic. The analysis of the legal epidemiology uses this as a starting date.

${ }^{75}$ To double check the quantitative data, searches then ran searches using any phraseology or language from the topical analysis.
} 
in the legal and legislative progression of the teen sexting epidemic. This is shown in Charts III and IV.

\section{Chart I}

Amount of Media Coverage (as measured by number of sources)

\begin{tabular}{|l|l|}
\hline $\begin{array}{l}\text { Coverage prior to } \\
\text { October } 2009\end{array}$ & 29 \\
\hline $\begin{array}{l}\text { Coverage after } \\
\text { October } 2009\end{array}$ & 168 \\
\hline Total Coverage $=$ & 197 \\
\hline
\end{tabular}

\section{Chart II}

\section{Teen Sexting: Topic Coverage}

\begin{tabular}{|c|c|}
\hline $\begin{array}{l}\text { Topics Included } \\
\text { (October 2009-June 2011) }\end{array}$ & $\begin{array}{l}\text { Number of Sources in } \\
\text { Which Mentioned }\end{array}$ \\
\hline $\begin{array}{l}\text { NCPTP/ Cosmogirl survey } \\
(20 \%)\end{array}$ & 21 \\
\hline Sext + prosecution ${ }^{76}$ & 68 \\
\hline Sext + child pornography & 92 \\
\hline Sext + suicide ${ }^{77}$ & 49 \\
\hline Sext + law/ legislation & 83 \\
\hline
\end{tabular}

\footnotetext{
${ }^{76}$ This includes references to George Skumanick"es prosecution as well as to other child pornography or similar prosecutions.

77 This includes references to Jessica Logan or Hope Whitsell.
} 


\section{Chart III: Timeline of Primary Coverage Topics}

January 2009-June 2011
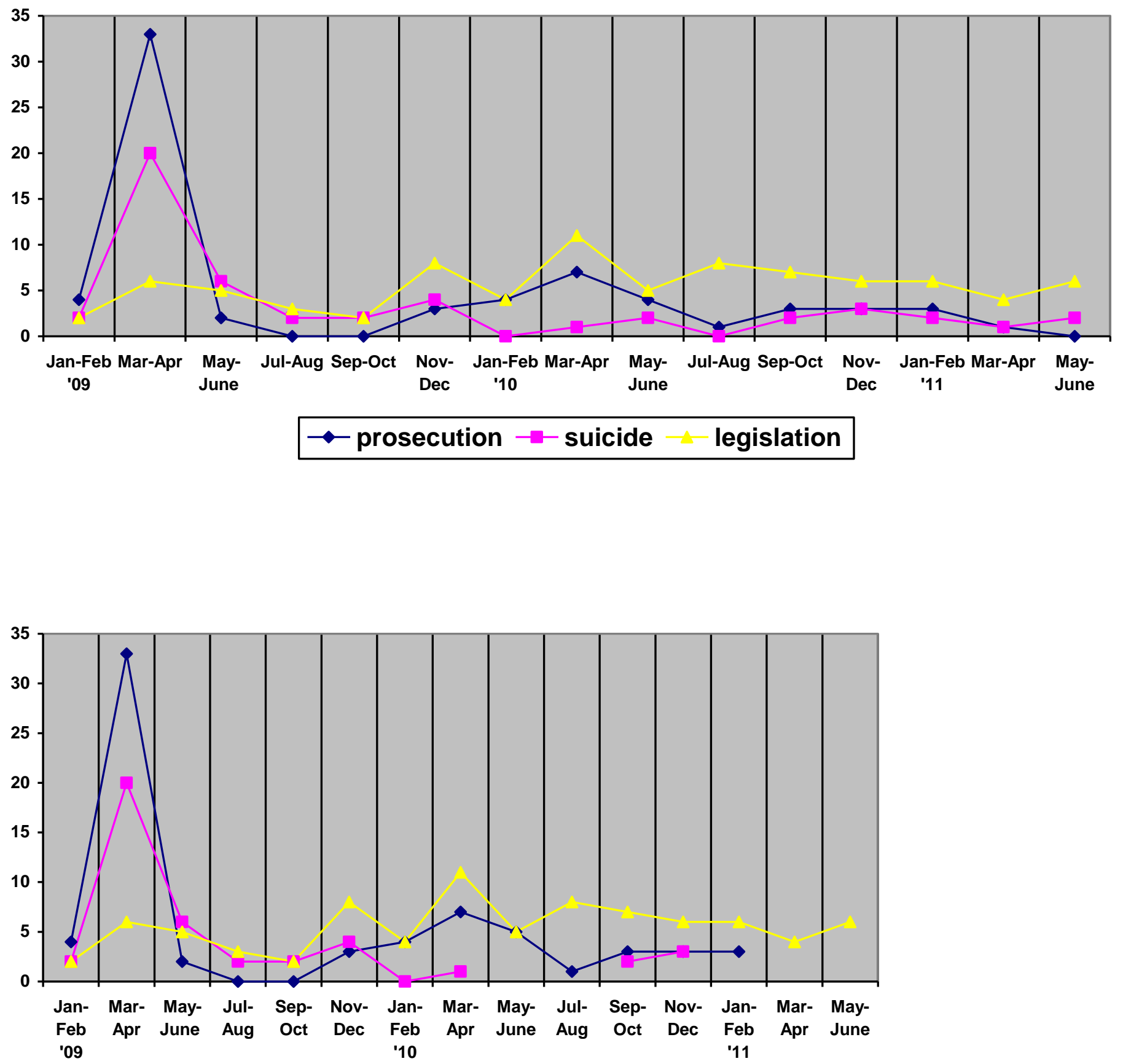


\section{Chart IV: Relationship between Coverage of Sext Prosecutions and Coverage of Sext- Related Suicide}

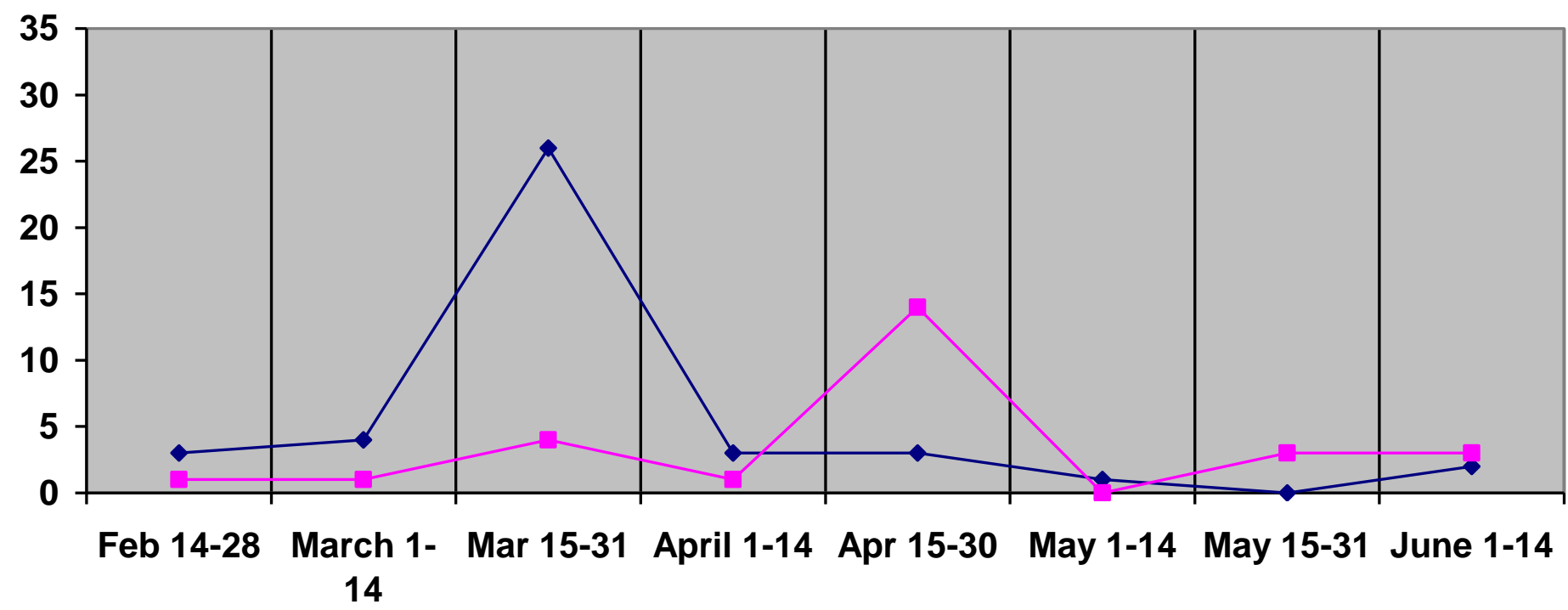

\section{THE MEDIA'S COVERAGE OF SEXT MESSAGING}

The study suggests that the media"s coverage of sext messaging reflects a dichotomy between adult sexting and teen sexting. ${ }^{78}$ Although sexting is more popular among adults than teens,${ }^{79}$ the media shows little interest in it. Rather, adult sexting garners coverage only as a way to spice up one $e^{\text {ee }}$ sex life $^{80}$ or when it involves politicians, celebrities, or professional athletes. ${ }^{81}$ Yet even with celebrity sexting, the media typically focuses on what the sexting evidences, rather

\footnotetext{
${ }^{78}$ See, e.g., Brooks, supra note 29, at 32.; see also Mike Males, Behaving Like Children, NY TIMES, Jan. 29, 2011, at A23. Males observed that the media treats teen behavior differently and consistently frames, "just about anything young people from the ages 10 to 19 do -- even feeling too good -- can be recast as a "teenage crisis."

${ }^{79}$ Amanda Lenhart et. al, Teens, Adults \& Sexting: Data on sending \& receipt of sexually suggestive nude or nearly nude images by American adolescents \& adults, Pew InTERnet \& AMERICAN LifE Project (October 23, 2010), http://www.pewInternet.org/Presentations/2010/Oct/Teens-Adults-and-Sexting.aspx. According to the Pew Report, 13\% of adults 18-29 have sent, and 31\% have received sexts. Additionally, $17 \%$ of $30-49$ year olds sext, 33\% of $18-29$ year olds sext, and $25 \%$ of adults age 18-49. Id.

80 Jessica Leshnoff, Sexting Not Just for Kids, AARP (June 2011), http://www.aarp.org/relationships/love-sex/info-112009/sexting_not_just_for_kids.html; see also The Sex Toy Hiding in Your Purse, Cosmopolitan Magazine, http://www.cosmopolitan. com/sex-love/tips-moves/The-Sex-Toy-Hiding-in-Your-Purse; Fields, supra note 7, at Sec. B; Hoffman, supra note 10, at 1; Schapiro, supra note 10.

${ }^{81}$ Terence Blacker, Why This Craze For 'Sexting' Is A One (Man) Show, Belfast Telegraph, Nov. 25, 2010 , at 28 ("the media have been amusingly muddled in their reaction to texting scandals"); see also Timson, supra note 11, at L1 (saying the rule used to be "If it bleeds, it leads" has been replaced by "If he cheats, it tweets").
} 
than the expression of sexuality. For example, with Tiger Woods, ${ }^{82}$ Brett Favre, ${ }^{83}$ and Anthony Weiner, ${ }^{84}$ the media focused on how the sexting revealed their marital infidelities, ${ }^{85}$ vain recklessness, ${ }^{86}$ and dishonesty in attempting to cover up their deeds. ${ }^{87}$

\section{THE OUTBREAK OF "TEEN SEXTING"}

The media covers teen sexting differently. ${ }^{88}$ This is evidenced both by the way the media presents the issue as well as by the fact that it devotes so much attention to it.

Quantitative analysis shows that between January 2006 and December $2008,{ }^{89}$ teen sexting was mentioned in forty sources. Between January 2009 and June 2011, teen sexting was mentioned in 168 sources. Furthermore, seventy-one of those mentions occurred from February 2009 to May 2009 alone, comprising forty-two percent of coverage.

All in all, the integrative analysis reveals four phases of teen sexting coverage: (1) a very sharp spike in March and April 2009 (comprised of coverage about child pornography prosecutions and sext-related suicide); (2) a spike in December 2009 (corresponding with the release of the Pew Research Centeres Teens and Sexting report); (3) an uptick in March 2010 (after the Third Circuites decision in a teen sexting case); and (4) from December 2009 to June

\footnotetext{
82 James Surowiecki, The Financial Page: Branded a Cheater, NEw Yorker, Dec. 21, 2009, at 52. Tiger Woods sexts exposed him as a cheater.

${ }^{83}$ Cam Hutchinson, Bits and Pieces, The Gazette (Montreal), Aug. 7, 2010, at D2 (Brett Favre sending sexts to a sideline reporter); Rupert Cornwell, Favre's Fall Latest Blow To Image Of All-American Hero, The InDEPENDENT (London), Oct. 19, 2010 , at 50.

${ }^{84}$ Brooks, supra note 29, at 32 (Weiner"s sexts demonstrated infidelity); Michael Daly, You're Outta School, So Grow Up, Anthony, The NY Daily News, June 7, 2011, at 5 (criticizing Weiner for lying to cover up his transgressions, engaging in the behavior of a high-schooler).

${ }^{85}$ Hannah Betts, 'Sexting': The New Infidelity; Celebrity Culprits Are Just The Tip Of The Sex-Sexting Can B Bad 4 Ur Marriage, Belfast TELEGRAPH, Feb. 27, 2010, at 22; Blacker, supra note 81, at 28; Timson, supra note 11, at L1..

${ }^{86}$ Brooks, supra note 29 , at 32 (Weiner was undone by his own vanity and sense of power); Mike Bianchi, Athletes Tweeting Badly; Twitter It Used to be What Happened in Vegas Stayed in Vegas - Not Anymore, The GaZette (Montreal), Aug. 28, 2010, at D3 (athletes" technological carelessness is bringing them down).

${ }^{87}$ The legal system ${ }^{\text {ee }}$ treatment of adults ${ }^{\text {ee }}$ self-created sexual media reflects a similar perspective. Typically, it presumes the creation and sharing of such material is private, and intervenes only when one of the parties seeks it, as with a civil lawsuit. A celebrity could sue an individual who seeks to distribute a sex tape, or a girl who went wild can assert that an underlying contract lacked a meeting of the minds or consideration, but the criminal justice system seldom intervenes.

${ }^{88}$ Arcabascio, supra note 9, at 9; Males, supra note 78, at A23L.

${ }^{89}$ This date coincides with the release of the Cosmogirl survey.
} 
2011, a slight, but relatively steady stream (comprised of coverage about sexting legislation).

Qualitative analysis shows that each of these phases relates to a topic or event that advanced or impacted the legal and legislative responses to sexting. Each is discussed below.

\section{RATE OF INFECTION: THE PREVALENCE OF SEXTING}

The quantitative analysis reveals that teen sexting burst into headlines in March 2009. Although that initial coverage began with and can be attributed to child pornography prosecutions of teen sexters, the concept of the teen sexting epidemic can be traced to a survey conducted by the National Campaign to Prevent Teen and Unplanned Pregnancy and Cosmogirl Magazine in October 2008. ${ }^{90}$ This survey, the first of its kind, claimed that almost twenty percent of teens were sexting. ${ }^{91}$

The quantitative analysis shows that initially the survey"s results went unnoticed by the media. ${ }^{92}$ Evidently, the statistics without context did not resonate: After all, if the fact that twenty percent of adolescents were sexting constituted an issue critical to society, then one would expect media coverage of it to increase soon after the survey"s October release, but it did not. Yet, when combined with reports of teens being prosecuted for sexting, this survey information achieved a new relevance. Indeed, the survey was first mentioned in a January 27 ,

\footnotetext{
${ }^{90}$ Calvert, supra note 28, at 21-22; see also The National Campaign to Prevent Teen and Unplanned Pregnancy ("NCPTUP"), Sex and Tech: Results from a Survey of Teens and Young Adults, at 1 (Oct. 3, 2008), available at http://www.thenationalcampaign.org/SEXTECH/PDF/SexTech_Summary.pdf. (This survey sought to, inter alia, "better understand the intersection between sex and cyberspace" and "quantify the proportion of teens and young adults that are sending or posting sexually suggestive text and images.")[hereinafter Cosmogirl Survey]. Although the partnership of Cosmogirl and NCPTUP may seem unusual, there may a common thread of conservatism. Research has found that teen magazines are more conservative in their sexual content (than are pop culture magazines) and associated with less accepting attitudes about nontraditional sexual practices and sexualities. See also Jerel P. Calzo \& L. Monique Ward, Media Exposure and Viewers' Attitudes Toward Homosexuality: Evidence for Mainstreaming or Resonance? 53 J. BROADCASTING \& ElECTRONIC MEDIA 280, 294-95 (2009).

${ }^{91}$ That survey included a total of 1,280 participants. Of the 653 13-19 year olds responding, just under $20 \%$ said they had posted online or sexted nude or semi-nude pictures or videos of themselves. Cosmogirl Survey, supra note 90, at 1, 5.

92 Calvert, supra note 28, at 9-10; "Sexting" Shockingly Common Amongst Teens, CBS NewS (Jan. 15, 2009), http://www.cbsnews.com/stories/2009/01/15/national/main4723161.shtml.
} 
2009 newspaper article ${ }^{93}$ and a March 11, $2009{ }^{94}$ radiobroadcast reporting that girls had been charged with child pornography for sexting.

By spring 2009 , the media was saturated with stories ${ }^{95}$ that teen sexting was reaching epidemic proportions, ${ }^{96}$ and warning that minors were distributing self-produced child pornography "at an alarming rate." 97 Meanwhile, because the Cosmogirl survey was the only source of data about teen sexting, it became the authoritative source of data about teen sexting. ${ }^{98}$ In this context, the sexting proclivities of 120 or so survey respondents now constituted proof of

\footnotetext{
${ }^{93}$ Stephanie Clifford, Teaching Teenagers About Harassment, NY TimES, Jan. 26, 2009, at B1; Ruth Marcus, Keeping Kids From One Byte Too Many, Washington Post, Apr. 1, 2009, at A21. The next major news article was, Donna Leinwand, Survey: 1 in 5 teens 'sext' despite risks; Racy Messages Open Doors For 'Cyberbullies' And Other Predators, USA ToDAY, June 24, 2009, at $3 \mathrm{~A}$.

${ }^{94}$ Sexting, Baseball, National Public Radio (Mar. 13, 2009)(referring to previous nightees profile of 16 year old who was arrested when her school found her sext message).

95 A significant number of these ran in March or April. See e.g., MSNBC, Girl Posts Nude Pics, Is Charged With Kid Porn, Mar. 27, 2009, http://www.msnbc.msn.com/id/29912729; Lance Benzel, Teens Won't Face Trial for Cell Phone Sex Photos, ThEGAZETTE (Colorado Springs), Apr. 10, 2009, http://www.gazette.com/articles/children-51546-office-case.html?referrer=digg; The Perils of Teen Sext, CHI. TRIB., Apr. 20, 2009, http://articles.chicagotribune.com/2009-04-20/news/0904190088_1_sextingchild-pornography-teen; Sherryl Connelly, No Sexting Students! Houston School District Bans Sexually Explicit Text Messages, NY DAILY NEws, Aug. 26, 2009, http://articles.nydailynews.com/2009-08-26/entertainment/29436360_1_sexting-nude-picturechild-pornography; Deborah Feyerick \& Sheila Steffen, "Sexting" Lands Teen on Sex Offender List, CNN, Apr. 8, 2009, http://www.cnn.com/2009/CRIME/04/07/sexting.busts/index.html; Mike Galanos, Commentary: Is 'Sexting' Child Pornography?, CNN, Apr. 8, 2009, http://www.cnn.com/2009/CRIME/04/08/galanos.sexting/; Ellen Goodman, Is 'Sexting' Same as Porn?, Boston Globe, Apr. 24, 2009, http://www.boston.com/bostonglobe/editorial opinion/oped/articles/2009/04/24/is sexting same as porn; Wendy Koch, Teens Caught 'Sexting' Face Porn Charges, USA ToDAY, Mar. 11, 2009, http://www.usatoday.com/tech/wireless/2009-03-11-sexting N. htm; Dahlia Lithwick, Teens, Nude Photos and the Law, NEwSwEEK, Feb. 23, 2009, http://www.newsweek.com/2009/02/13/teens-nude-photos-and-the-law.html; Ben O'Brien, Editorial, To Deal With 'Sexting,' XXXtra Discretion is Advised, USA TodAY, May 5, 2009, http://content.usatoday.com/topics/post/USA+TODAY+editorial/66374679.blog/1; Bianca Prieto, Teens Learning There Are Consequences to "Sexting," Seattle Times, Mar. 11, 2009 (quoting an advisor for the National Campaign to Prevent Teen and Unplanned Pregnancy); Bianca Prieto, 'Sexting' Teenagers Face Child-Porn Charges, Orlando Sentinel, Mar. 8, 2009, http://www.orlandosentinel.com/news/local/orl-asec-sexting-030809,0,938390; Bianca Prieto, Teens Learning There Are Consequences to "Sexting," SEATtle Times, $\quad$ Mar. http://seattletimes.nwsource.com/html/nationworld/2008845324_sexting12.html; Riva Richmond, Sexting May Place Teens at Legal Risk, NY TIMES, Mar. 26, 2009, http://gadgetwise.blogs.nytimes.com/2009/03/26/sexting-may-place-teens-at-legal-risk/; Jeffry Scott, Sexting Stumps State's Schools, Prosecutors, Atlanta J.-Const., Apr. 22, 2010, at A1; Gigi Stone, "Sexting' Teens Can Go Too Far, ABC News, Mar. 13, 2009, http://abcnews.go.com/Technology/WorldNews/sexting-teens/story?id=6456834; Kelli Wynn, Middle School Student Won't Be Charged For Sexting, Dayton Daily News, Mar. 24, 2009, http://www.daytondailynews.com/localnews/content/oh/story/news/ local/2009/03/24/ddn032409sextingweb.html?cxtype=rss $\S$ cxcat $=16$.

96 Murad Ahmed, Police Warn Over Rise of Teenage "Sexting" Trend, SundAY TIMES, Aug. 5, 2009, http://technology.timesonline.co.uk/tol/news/tech_a nd_web/article6738532.ece (quoting Will Gardner, Chief Executive of Childnet International); see also Calvert, supra note 28, at 21-22 (detailing the multiple and various media sources reporting on teen sexting); Day, supra note 5, at 70 (discussing how sexting has become commonplace among teens); Julia Halloran McLaughlin, Crime and Punishment: Teen Sexting in Context, 115 PenN ST. L. Rev. 135, 136 (2010); Kowalczyk, supra note 23, at 686; Males, supra note 78, at A23 (asserting that the news media continued to assert alarming claims of an unsubstantiated sexting epidemic); Walters, supra note 10, at 101 (discussing texting as not only an epidemic deserving of adult hysteria but as a form of explorative communication).

97 Mary Graw Leary, Self-Produced Child Pornography: The Appropriate Societal Response To Juvenile Self-Sexual Exploitation, 15 VA. J. SOC. POL'Y \& L. 1, 4 (2007).

${ }^{98}$ Calvert, supra note 28 , at 21-22.
} 
a nationwide epidemic of teen-produced child porn. ${ }^{99}$ As news reports referenced this statistic and cross-pollinated each other, the prevalence of teen sexting became conventional wisdom. ${ }^{100}$

Nonetheless, the survey's methodology ${ }^{101}$ has been criticized. With regard to its raw data, a researcher in a three year study investigating teens and digital behaviors determined that the Cosmogirl numbers were inflated. ${ }^{102}$ With regard to its data and interpretation data, it combined the responses of eighteen and nineteen year-old adults with those of the thirteen to seventeen year olds. This inflated the proportion of actual teens sexting. ${ }^{103}$ A Cox Communications/ Harris Interactive online survey ${ }^{104}$ of thirteen to eighteen year olds, however, found that nineteen percent ${ }^{105}$ had sent, received, or forwarded sexually suggestive nude or nearly nude photos by text or email, ${ }^{106}$ and a 2009 MTV/ Associated Press online survey ${ }^{107}$ reported that twenty-four percent of fourteen to seventeen year olds were involved in "some type of" sexting. ${ }^{108}$

Perhaps the most authoritative source on teen digital behaviors is the Pew Research Center"es Internet and American Life Project, a non-profit, non-partisan "fact tank." The Pew

\footnotetext{
${ }^{99}$ Calvert, supra note 28, at 21; see also Stephanie Steinberg, 'Sexting' Surges Nationwide, And It's Not Just Teens Doing It; Young People Must Be Careful, Experts Say, USA Today, Jul. 21, 2010, at 08D; Nathan Koppel \& Ashby Jones, Are 'Sext' Messages A Teenage Felony Or Folly, Wall St. J., Aug. 25, 2010, at D1 (discussing whether teenage ,sextinge should be a crime).

${ }^{100}$ In light of the intersecting issues of sex, teens, and technology, the media attention was not surprising: When adolescents are involved, advocacy groups and sensationalist media recast "just about anything young people" do as a "teenage crisis." Males, supra note 78 , at 23

${ }^{101}$ Calvert, supra note 28 , at 10 .

${ }^{102}$ UPI, Newswire, Dateline ChiCago, Jan. 11, 2009, (quoting Professor C.J. Pascoe).

${ }^{103}$ In other words, if just under 20\% of 13-19 year olds sext, then once $18-19$ year olds are excluded, less than just under $20 \%$ of 13-17 year olds sext. In addition, the survey collapses online photo posts with cell phone sexts.

${ }^{104}$ Cox Communications, Teen Online \& Wireless Safety Survey Cyberbullying, Sexting, and Parental Controls 34, May 2009, http://www.cox.com/takecharge/safe_teens_200 9/media/2009_teen_survey_Internet_a nd_wireless_safety.pdf [hereinafter Cox Communications].

${ }^{105}$ Cox Communications, supra note 104, at 34. (655 teenagers participated in the Cox survey).

${ }^{106}$ Cox Communications, supra note 104, at 34.

107 A Thin Line: 2009 AP-MTV Digital Abuse Study Executive Summary, Dec. 2009, http://www.athinline.org/MTVAP_Digital_Abuse_Study_Executive\&us core;Summary.pdf [hereinafter MTV Survey] (1,247 participants ages 14-24); The MTV-Associated Press Poll: Digital Abuse Survey, Sept. 23, 2009, http://www.athinline.org/MTVAP_Digital_Abuse_Study_Full.pdf [hereinafter MTV-AP Poll]; MTV Survey, at 6 n.1, MTV-AP Poll, at 11-2 (this online survey examined a constellation of 17 "digitally abusive behaviors," including sharing an email or instant message that had been sent to another person, putting embarrassing pictures or video of the youth on the Internet without his or her permission, taking sexual photos without the youth's knowledge and sharing them, and pressuring youth to take naked pictures or video).

${ }^{108}$ MTV-AP Poll, supra note 107, at 2.
} 
Research Center"s December 2009 report, Teens and Sexting: How and Why Minor Teens Are Sending Sexually Suggestive Nude or Nearly Nude Images Via Text Messaging ${ }^{109}$ determined that teen sexting was not nearly as common as the Cosmogirl numbers suggested. ${ }^{110}$ Pew surveyed twelve to seventeen year olds concerning sending or receiving by cell "sexually suggestive nude or nearly nude photos or videos of themselves or of someone they knew."111 The Pew Survey found that four percent of teens overall (or five percent of the fourteen to seventeen year olds) had sexted such photos or videos of themselves and fifteen percent overall (or eighteen percent of the fourteen to seventeen year olds) had received one. ${ }^{12}$

As shown in Chart III, coverage of teen sexting spiked a second time in December 2009. Analysis of story content shows that this spike corresponded with and can be attributed to the release of the Pew Report. In fact, all but one source during that period referenced either the Pew Report or the prevalence of teen sexting. Therefore, while the Cosmogirl survey did not ignite media interest, the Pew Report, having been released in an environment in which the public had become aware of teen sexting and the issue was germinating, produced a different response.

Therefore, despite teen sextinge's popularity in the media, ${ }^{113}$ its prevalence in the real world is uncertain. ${ }^{114}$ Additionally, regardless of the study cited, the data can be interpreted

\footnotetext{
109 Amanda Lenhart, Teens and Sexting, Pew Research Center, Dec. 15, 2009, http://pewinternet.org/ /media//Files/Reports/2009/PIP_Teens_and_Sexting.pdf. .

${ }^{110}$ Lenhart, supra note 37 , at 87.

${ }^{111}$ Lenhart, Sexting, supra note 109, at 2. The Pew Survey focused on three "sexting" scenarios (1) pictures shared or forwarded between two romantic partners "in lieu of, as a prelude to, or as part of, sexual activity;" (2) images sent between friends or between two people where at least one person is hoping to become romantically involved; (3) images forwarded with or without the subject's knowledge to others). Id. at 6-8.

${ }_{112}$ Lenhart, Sexting, supra note 109 , at 5.

113 Kowalczyk, supra note 23, at 686; Shafron-Perez, supra note 10, at 432-33. (ironically, publicizing teen sexting and portraying it as common may contribute to teen sexting by leading teens to believe that everybody is doing it); Hoffman, supra note 10 (teens sext to be cool and obtain cachet); see generally Podlas, supra note 44, at 17-9 (when media publicizes behaviors as normal, cultural barriers to engaging in those behaviors diminish).

114 Arcabascio, supra note 9, at para. 45 (notwithstanding sexting prosecutions, there is nothing to suggest sexting is an "epidemic"); Fulton, supra note 1 (“[1]ike many sensationalist developments, this one may be oversold"); Kowalczyk, supra note
} 
positively or negatively. Some people use these statistics to prove that sexting is rampant (because twenty percent of teens sext), while others use them to show that it is not (because eighty percent do not sext). ${ }^{115}$

\section{AGENDA SETTING}

More important than whether there was (or is) an objectively verifiable epidemic of teen sexting $^{116}$ - let alone one warranting legislation - is that in Spring 2009 there was an epidemic of media coverage about it. This brought the issue to the attention of the public and signaled that teen sexting was an important issue. As coverage of the sexting progressed, so did the concern of the public and lawmakers. This exemplifies the media phenomenon known as "agenda setting."

In American society, many issues compete for attention, but relatively few reach the public agenda. ${ }^{118}$ Quantitative analyses have found that the primary factor in whether an issue becomes part of the public agenda is the amount of airtime or press devoted to it. ${ }^{119}$ Research shows that when the media devotes a significant amount of attention to a particular issue, the public will come to consider that issue salient. ${ }^{120}$ Essentially, by featuring the issue, the media

23, at 688-90 (limited amount of research on sexting); McElroy, supra note 4, at 16 (overreaction of media and prosecutors). No studies have investigated how many teens regularly sext message, as opposed to experimenting with or passively receiving sexts.

${ }^{115}$ Tim Barker, Sext And The City. Study On Teens, Cell Phones And The Sharing Of Nude Images Finds That Many More Teens Receive Sext Messages Than Send Them, Suggesting That They Are Being Passed Around, ST. Louis DisPatch, Jan. 18, 2010, at A3.

${ }^{116}$ Fulton, supra note 1; McElroy, supra note 4, at 16; Males, supra note 78, at 23 (media"s unsubstantiated claims of new sexting epidemic); Calvert, supra note 28, at 21-22; Carl Bialik, Which Is Epidemic - Sexting or Worrying About It? WALL ST. J., Apr. 8, 2009, http://online.wsj.com/article/SB123913888769898347.html (sexting is not as rampant as media coverage implies).

${ }^{117}$ Melvin L. DeFleur \& SAndra, Ball-Rokeach, Theories of Mass Communication (5th ed. 1989).

118 Maxwell McCombs \& Amy Reynolds, News Influence on Our Pictures of the World, in Media Effects: Advances in Theory And Research 1-3 (Jennings Bryant \& Dolf Zillman, eds., 2002).

119 Bryant \& Zillman, supra note 118, at 4-9; Dennis T. Lowry, et al., Setting the Public Fear Agenda: A Longitudinal Analysis of Network TV Crime Reporting, Public Perceptions of Crime, and FBI Crime Statistics, 53 J. ComMC"N 61 (2003).

${ }_{120}$ Margaret Bull Kovera, The Effects of General Pretrial Publicity on Juror Decisions: An Examination of Moderators and Mediating Mechanisms, 26 LAW \& Hum. BeHAV. 43, 45-46 (2002); Bryant \& Zillman, supra note 118, at 4-9 (airtime devoted to issue); Shanto Iyengar \& DONALD R Kinder, News That MATTERs (Chicago: University of Chicago, 1987); Lowry, supra note 119 , at 61. 
deems it worthy of attention, and the public considers it important. In this way, the media helps set the public agenda. ${ }^{121}$

For example, though violent crime declined during the 1990s, news coverage of it increased. $^{122}$ This attention implied that crime was a significant concern. Consistent with the media coverage, surveys show that the publice ${ }^{\text {e }}$ concern about crime increased. ${ }^{123}$ Similarly, in the 1980s, news stories about frivolous litigation and out of control juries began to increase, until they reached fever pitch in the 1990s." ${ }^{124}$ By that point, the public accepted the "litigation explosion" as a fact and considered it an important issue. This coverage also shaped (and was shaped by) the legislative agenda of tort reform and capping punitive damages. ${ }^{125}$

Indeed, deeming an issue important can impact the legislative agenda by designating the issue worthy of legislation or laying the foundation for particular types of legal intervention. ${ }^{126}$ The media played such a role in federal child pornography and sex offender registration laws. ${ }^{127}$ In the late 1970s, its coverage of child pornography brought the issue to light. Soon after, Congress held hearings and passed federal child pornography legislation. ${ }^{128}$ Two decades later, media coverage was a catalyst in national sex offender registration laws. ${ }^{129}$ Obviously, children had been abducted and abused in the past, but it was not until the media devoted significant

121 William Haltom \& Michael McCann, Distorting the Law 29, 270 (2004); R. Lance Holbert et al., Environmental Concern, Patterns of Television Viewing, and Pro-Environmental Behaviors: Integrating Models of Media Consumption and Effects, 47 J. BROAD. \& ElEC. MEDia 177, 179-80 (2003) (citing studies that news media"s attention to an issue influences whether public believes issue is salient).

${ }^{122}$ Daniel Romer, et al., Television News And The Cultivation Of Fear Of Crime, 53 J. CommC'N 88 (2003).

${ }^{123}$ Lowry, supra note 119, at 61; Podlas, Funny, supra note 3, at 300-02.

${ }^{124}$ Marc S. Galanter, Reading The Landscape Of Disputes: What We Know and Don't Know (and Think We Know) About Our Allegedly Contentious And Litigious Society, 31 UCLA L. REV. 154-55 (1983); Podlas, supra note 44, at 3-15.

${ }_{125}$ Podlas, supra note 44, at 8-13. There was little statistical evidence of a litigation explosion, however. Id.

126 These became the foundation for the American tort "reform" movement, which included legislation setting damage caps and liability limits to protect "victimized" businesses. VALERIE P. HANS, Business ON TRIAL 56-8 (2000); Jennifer K. Robbennolt \& Christina A. Studebaker, News Media Reporting on Civil Litigation and Its Influence on Civil Justice Decision Making, 27 L. \& Human BehaV. 27 (2003); see also Carpenter, supra note 2, at 2-3 (increased rhetoric can lead to flurry of legislation).

${ }^{127}$ Bryn Ostrager, Special Issue: Ensuring Access to Justice for Self-Represented Litigants: Additional Student Note: SMS. OMG! LOL! TTYL: Translating the Law to Accommodate Today's Teens and the Evolution from Texting to Sexting, 48 FAM. CT. REV 712, 713-14 (2010).

${ }^{128}$ Id. at 714 .

${ }^{129}$ See, e.g., Adam Walsh Child Protection \& Safety Act of 2006, Pub. L. No. 109-248, 120 U.S.C. § 587 (2006). 
attention to the stories of particular victims ${ }^{130}$ that the public and politicians conceptualized the issue as one in need of legislative action. ${ }^{131}$

With regard to teen sexting, the media's prolific coverage of it cultivated public perception that it was an important issue. As coverage progressed to include the legal implications, the public and policymakers came to believe that these deserved attention, ${ }^{132}$ including legislation. Importantly, the agenda setting effect here rests not on the actual frequency of teen sexting or whether the issue was more important to the nation than others, but on the amount of coverage it attracted. This underscores that the causal relationship is between the amounts of media coverage on perception of issue salience. Hence, abundant coverage does not mean that an issue is objectively important. Consequently, excessive media interest can elevate an unimportant issue or make a random occurrence seem in need of attention. This is especially relevant in analyzing the emergence of the teen sexting epidemic and the legal and legislative responses to it.

\section{FRAMING TEEN SEXTING AS CHILD PORNOGRAPHY}

Although this provides insight into how teen sexting became part of the national conversation, it does not explain how the public and lawmakers came to understand it as a criminal problem requiring legislative intervention.

As shown in Chart III, the issue of teen sexting did not emerge in the media until the epidemic of coverage in March and April 2009. According to the results of the qualitative analysis, this coverage focused on the Skumanick child pornography prosecution and similar

\footnotetext{
${ }^{130}$ Carpenter, supra note 2, at 2-3, 12-3.

${ }^{131} \mathrm{Id}$. at $1-3$. Virtually all sex offender registration laws are named after a victimized child who was introduced to the public by the media. Id. at 18-21.

132 David Kelly, Yucaipa Teen Cited for 'Sexting' Nude Photos of Classmates, L.A. Times, Apr. 15, 2010, http://articles.latimes.com/2010/apr/15/local/la-me-teen-sexting15-2010apr15; Day, supra note 5, at 71-72; Leary, supra note 97, at 4; Macleod-Ball, supra note 16, at 129; Walters, supra note 10, at 101.
} 
cases throughout the country. ${ }^{133}$ In February 2009, Pennsylvania District Attorney George Skumanick threatened to prosecute several teens for child pornography because they had sexted photos. $^{134}$

Though every court that eventually heard the case criticized this threat of prosecution, and Skumanick would lose the case as well as his job, ${ }^{135}$ this child porn label forever framed the teen sexting debate. It became the foundational theory for analyzing teen sexting and its regulation. This case exemplifies the operation and effects of media framing. Indeed, prior to October 2008 (the release of the Cosmogirl survey), no articles discussed teen sexting in terms of child pornography. After October 2008, 130 teen sexting articles referenced either child pornography prosecutions or ameliorative legislation.

\section{THE CHILD PORNOGRAPHY PROSECUTIONS}

In late 2008, school administrators in Pennsylvania searched and found on students' cell phones photos of "scantily clad, semi-nude and nude teenage girls." ${ }^{136}$ One photo showed Marissa Miller and Grace Kelly wearing white bras as one girl talked on the phone and the other made a peace sign. ${ }^{137}$ Another photo showed Nancy Doe wearing a towel "wrapped around her body, just below her breasts." ${ }^{138}$ The school notified District Attorney Skumanick.

\footnotetext{
${ }^{133}$ Halloran McLaughlin, supra note 96, at 138-39 (surge in teen sexting prosecutions); Prosecutors Gone Wild, supra note 7, at 30.

${ }^{134}$ Miller v. Skumanick, 605 F. Supp. 2d 634 (M.D. Pa. 2009), aff'd Miller v. Mitchell, 598 F.3d 139 (3d Cir. 2010) ; Miller v. Mitchell, No. 3:09cv540, 2010 WL 1779925 (M.D. Pa. 2010) (granting permanent injunction).

${ }^{135}$ Josh McAuliffe Wyoming County District Attorney Falls in Election, Times-TriB. (Scranton, PA), Nov. 4, 2009 (noting the sexting prosecution; the 6-term Republican was defeated by the grass roots campaign of Democrat Jeff Mitchell); see Miller v. Mitchell, 598 F.3d at 139 (Mitchell, in his official capacity as District Attorney, was substituted (pursuant to Federal Rule of Appellate Procedure 43(c)(2)) as the named Defendant in the appeals).

${ }^{136}$ Miller v. Skumanick, 605 F. Supp. 2d at 637.

${ }^{137} I d$.

${ }^{138}$ Id. at 637-39; Sherman, supra note 15, at 153-54.
}

PGH. J. TeCh. L. \& POL ${ }^{e} Y$, Vol. 12, No. 1, Fall 2011 
These photos would not constitute child pornography under federal law or Supreme Court jurisprudence: ${ }^{139}$ The Supreme Court has repeatedly stated that nudity alone does not amount to child pornography. ${ }^{140}$ Rather, visual material must depict a minor engaging in sexually explicit conduct. $^{141}$ Neither exposed breasts nor holding a phone while wearing underwear approaches this definition. In fact, the state statute on which Skumanick relied ${ }^{142}$ does not criminalize merely nude photos. ${ }^{143}$

Notwithstanding, in February 2009, Skumanick began to pursue a child pornography case against the girls who possessed or had appeared in the sexts. ${ }^{144}$ (Although the school ${ }^{e e}$ initial discovery of the photos was due to boys sharing the photos, Skumanick did not charge them ${ }^{145}$ ). Skumanick insisted that the girls in the pictures were posing "provocatively," 146 thereby rendering them child pornography. ${ }^{147}$ Thus, girls who possessed the photos, possessed child pornography, and girls in them "were accomplices to the production of child pornography because they allowed themselves to be photographed."148

\footnotetext{
139 Although this is a Pennsylvania case, the federal child pornography law is being used as a benchmark of a constitutional child pornography statute as well as to represent a general understanding of child pornography.

${ }^{140}$ Osborne v. Ohio, 495 U.S. 103, 112 (1990); New York v. Ferber, 458 U.S. 747, 765, n. 18 (1982); Erznoznik v. City of Jacksonville, 422 U.S. 205, 213 (1975).

${ }^{141}$ Sexually explicit conduct includes, inter alia, the "lascivious exhibition of the genitals or public area". For instance, the United States Code defines "sexually explicit conduct" as "sexual intercourse, including genital-genital, oral-genital, anal-genital, or oral-anal, whether between persons of the same or opposite sex; bestiality; masturbation; sadistic or masochistic abuse; or lascivious exhibition of genitals or pubic area of any person." 18 U.S.C. § 2256(2)(A) (2010) (emphasis added).

142 18 PA. CONST. STAT. ANN. § 6312 (West 2010).

${ }^{143}$ See id. $\S$ 6312(b) (defining a "[p]rohibited sexual act" as including "lewd exhibition of the genitals or nudity if such nudity is depicted for the purpose of sexual stimulation or gratification of any person who might view such depiction").

${ }^{144}$ Skumanick, 605 F. Supp. 2d at 638-40.

${ }^{145}$ Bazelon, supra note 19; Skumanick, 605 F.Supp. 2d at 638; but see Miller, 598 F.3d at 144 (noting that it was unclear to whom letters were sent, and that Skumanick claimed that he had offered the program to three boys). At oral argument before the Third Circuit, the District Attorney"s office explained the decision not to charge the boys: "high school boys did as high school boys do and traded the photos among themselves." Id. Indeed, there may be a double standard when it comes to the social consequences of sext sharing, wherein girls are labeled sluts. Hoffman, supra note 10.

${ }^{146}$ Skumanick, 605 F. Supp. 2d at 638-39. Skumanick told reporters that students who possess "inappropriate" digital photos of minors expose themselves to possible prosecution for possessing or distributing child pornography. Miller, 598 F.3d at 143-45.

147 Skumanick, 605 F. Supp. 2d at 638-40; Miller, 598 F.3d at 143-44.

${ }^{148}$ Prosecutors Gone Wild, supra note 7, at 30; Day, supra note 4, at 77-78; ACLU Sues Wyoming County D.A. for Threatening Teenage Girls with Child Pornography Charges Over Photos of Themselves, ACLuPA.ORG (Mar. 25, 2009), http://www.aclupa.org/pressroom/aclusueswyomingcountydafor.htm.
} 
Skumanick sent letters to the parents notifying them that their children were involved in a child pornography investigation and set a mass meeting. ${ }^{149}$ At the meeting, Skumanick threatened to file felony child pornography charges against the teens unless they completed a six to nine months in an education and counseling program (which Skumanick created and ran under the auspices of the Probation Department), ${ }^{150}$ undergo supervised probation, and pay a $\$ 100$ fee. ${ }^{151}$ Among other things, the program would address "what it means to be a girl in today's society and non-traditional societal and job roles," and require each girl to write an essay describing why her actions were wrong and how they harmed the victim. ${ }^{152}$ Skumanick's only response to parents who questioned his assessment of the photographic content was that he would prosecute if they refused the program. Although most parents and teens acquiesced, the parents of Miller, Kelly, and Doe refused, insisting that they had done nothing wrong. ${ }^{153}$

On March 25, 2009, with the assistance of the Pennsylvania American Civil Liberties Union (ACLU), the girls and their parents filed a Motion for a Temporary Restraining Order (TRO) to prevent Skumanick from proceeding with legal action. A hearing was held the next day, and, on March 30, the Motion was granted. ${ }^{154}$ One year later, the Third Circuit affirmed that Order. ${ }^{155}$

\footnotetext{
149 Skumanick, 605 F.Supp. 2d at 638.

${ }^{150}$ Id. at 638-40; Wendy Davis, „Sext' Education: States Look For Ways To Chastise Teens For Sending Bawdy Cell Phone Shots, 97 ABA Journal 20 (May 2011).

${ }^{151}$ See Miller, 598 F.3d at 142-44. The $\$ 100$ was not a fine, but to cover the cost of the re-education program. Id. at 144 .

152 Skumanick, 605 F. Supp. 2d at 638-40; Miller, 598 F.3d at 145.

${ }^{153}$ See ACLU Sues, supra note 148.

154 Skumanick, 605 F. Supp. 2d at 637-40.

155 On March 17, 2010, the United States Court of Appeals for the Third Circuit affirmed a district court's grant of preliminary injunction against a sexting prosecution. Miller, 598 F.3d at 155. Subsequently, on April 30, 2010, the district court granted the Motion for a Permanent Injunction and permanently enjoined the District Attorney ${ }^{\text {ee }}$ Office from initiating further charges against the girls. Miller v. Mitchell, No. 3:09cv540, 2010 WL 1779925.
} 


\section{MEDIA COVERAGE OF CHILD PORNOGRAPHY PROSECUTIONS}

Within days of the TRO, national media reported this ${ }^{156}$ and a rash of similar cases across the country. ${ }^{157}$ The quantitative analyses show that there were fifty-two Skumanick prosecution stories over the period studied, but more than half of those were between March and April 2009. In fact, of those stories, forty-two percent were between March 25 (the date that the motion was filed) and March 27 (the day after the hearing on the motion). As noted, this also constituted the initial and sharpest spike in media coverage of teen sext messaging. There was a second uptick in Skumanick coverage one year later, coinciding with the Third Circuit"s affirmance of the TRO. ${ }^{158}$ News of these prosecutions and teen sexting epidemic dovetailed: Not only was there a teen sexting epidemic, but teens who sexted were being prosecuted as child pornographers.

Although their facts differed, all of the other cases involved a teenager and a photo deemed by a prosecutor to be a "sext." Therefore, these cases reinforced the very same legal framework as Skumanick, that of child pornography. ${ }^{159}$ For example, Indiana charged a teen with obscenity for sending a picture of his genitals to female classmates. ${ }^{160}$ Ohio charged a fifteen -year-old with a felony for sexting nude photos of herself to high school classmates. ${ }^{161}$ Virginia charged two high school students for sexting images to several twelve to sixteen-yearold girls. ${ }^{162}$ California cited four fifteen-year-old boys for "sexual exploitation of a minor" for

\footnotetext{
${ }^{156}$ Prosecutors Gone Wild, supra note 7, at 30; Galanos, supra note 95; Parrilla, supra note 18, at A1; Scott, supra note 95, at A1; Richmond, supra note 95; Michael Rubinkam, Girls Threatened with Porn Charge Sue Prosecutor, ABC NEWs, Mar. 25, 2009, http://abclocal.go.com/wpvi/story?section=news/local\&id=6727794.

${ }^{157}$ See Shafron-Perez, supra note 10, at 434; Marcus, supra note 93, at A21.

${ }^{158}$ See, Chart IV, supra page 12 (showing a spike on media coverage on March 17, 2010).

${ }^{159}$ Furthermore, the number of these prosecutions reported may have helped cultivate in the public a perception that both sexting and such prosecutions were common. See Podlas, Funny, supra note 3, at 296-97, 300-02 (explaining the cultivation effect on the publices perception of how frequently something occurs).

160 Ed Bushnell, Sweet "Sext"teen: When Child Pornography Victims Become Defendants, The LeGALITY, Feb. 19, 2009, http://www.thelegality.com/2009/02/19/sweet-sextteen-when-child-pornography-victims-become-defendants; Day, supra note 5, at 78 .

${ }^{161}$ Day, supra note 5, at 78; Girl, 15, Faces Child Porn Charges for Nude Cell Phone Pictures of Herself, FOX NEws, Oct. 9, 2008, http://www.foxnews.com/story/0,2933,434645,00.html.

162 Two Teens Charged in SpotsylvaniaSexting Case, NBC Washington, Mar. 11, 2009, http://www.nbcwashington.com/news/local/Two-Teens-Charged-in-Spotsylvania-Sexting-Case.html.
} 
posting online nude and semi-nude pictures of their classmates. ${ }^{163}$ Georgia charged a tenth grader with misdemeanor for furnishing obscene material to a minor, because he sent a naked picture of himself to a sixteen-year-old girl (who then forwarded it others, including a fourteen year-old). ${ }^{164}$ New York indicted a sixteen year-old for a felony because he sent a nude photo to his girlfriend. ${ }^{165}$ New Jersey charged a 14 year-old girl with child pornography because she posted nude and semi-nude photos of herself on her MySpace page. ${ }^{166}$ Florida convicted a sixteen and seventeen-year-old couple of child porn because the girl sent the boy a photograph of them engaged in a sexual act. ${ }^{167}$ Florida also convicted an eighteen-year-old high school senior of child pornography because he forwarded a nude picture his seventeen-year-old girlfriend sent to him (after the couple, who had been together for two and a half years, had a fight) to dozens of other people. $^{168}$

To the extent that these prosecutors equated a teen in some form of undress with a teen engaging in sexually explicit activity and the lascivious exhibition of their genitals (critical elements in the crime of child pornography), these prosecutions overreached. ${ }^{169}$ Notwithstanding, these cases (as transmitted to the public via the media) informed the public that teen sext messages constituted child pornography and the government had an obligation to intervene into the matter. The media even quoted prosecutors who insisted that they had no

\footnotetext{
${ }^{163}$ Day, supra note 5, at 78; see also Kelly, supra note 132.

${ }^{164}$ Scott, supra note 95; Day, supra note 5, at 78-9.

${ }^{165}$ Day, supra note 5, at 79; Susan L. Pollet, Teens and Sex Offenses: Where Should the Law Draw the Lines?, 242 N.Y.L.J. 4 (2009).

166 Beth DeFalco, 14-Year-Old Girl Arrested After Posting Nude Pics, ASSOCIATED PRESS, Mar. 27, 2009, http://www.netlingo.com/more/Girl_arrested.pdf; Friedman \& DeMarco, supra note 5, at 007.

${ }_{167}$ A.H. v. State, 949 So. 2d 234, 239 (Fla. Dist. Ct. App. 2007) (J.G.W. was charged with possession of child pornography under FLA. Stat. $\S 827.071$ (2009), promoting a sexual performance by a child).

${ }^{168}$ Feyerick \& Steffen, supra note 95; A Thin Line, Sexting in America (Part 1), MTV, http://www.athinline.org/videos/17sexting-inamerica-part-1 (Phillip Alpert told MTV's "Sexting in America" program that the incident occurred one month after he turned eighteen (when his girlfriend was seventeen)).

${ }^{169}$ See Rowland, supra note 3, at B 01.
} 
choice but to prosecute teens under child pornography and obscenity laws. ${ }^{170}$ In fact, while some members of the legal community observed sexting was an instance of technology outpacing the law, ${ }^{171}$ these prosecutions seemed to invoke this as a justification. In effect, the legal system was forced to look to other areas of the law, and when it did, it stumbled upon child porn and was forced to treat teen sexting as such. ${ }^{172}$ The mediae s child pornography coverage thereby supplied the dominant framework for understanding sexting as well as for considering responses to it.

\section{FRAMING}

Research regarding the mediaes influence on public opinion and legal issues shows the framework used to present an issue can impact the way people conceptualize it. ${ }^{173}$ When the media consistently frames ${ }^{174}$ an issue in a particular way, the public tends to adopt that frame in thinking about the issue. ${ }^{175}$ Although the media frame does not tell the public which conclusion to draw, by providing it with a specific framework within which to examine an issue, the media

\footnotetext{
170 Vallery Brown, District Attorney says His Only Option to Fight Trend is to Use Child Pornography Statutes, ThE Oklahoman, Jul. 29, 2010, at 11 A; Associated Press State and Local Wire, Investigation into Junior High Naked Photo Exchange growing, Apr. 1, 2008 (quoting County Attorney, "even if it"s consensual, such pictures are legally child pornography").

${ }^{171}$ The implication was that the legal system was ill-equipped to deal with it. U.S. v. Taylor, 640 F.3d 255, 264 (7th Cir. 2011); Sherman, supra note 16, at 139; Joyce, supra note 20; Parrilla, supra note 18; Pawloski, supra note 19, at A 004; see Treglia, supra note 18, at 415. It may be true that the pace of technology exceeded that of the law, but this is often true. New technologies create new problems, but also implicate concerns addressed by existing law and jurisprudence. And in each of those instances, the legal system looks for parallels with existing law and legal theory, while identifying any characteristics of new technology that might render existing law inapt. Hence, the "technology is faster than law" refrain is often a legal platitude, rather than an indication of great insight: it is true, but lacks meaning.

172 Brown, supra note 170, at 11A; Day, supra note 5, at 75; Arcabascio, supra note 9, at 1; Galanos, supra note 95; Judith Levine, What's the Matter with Teen Sexting?, AMERICAN ProsPeCt, Feb. 2, 2009, available at http://www.prospect.org/cs/articles?article=whats_the_matter_with_teen_sexting (citing arrests in Alabama, Connecticut, Florida, New Jersey, New York, Michigan, Ohio, Pennsylvania, Texas and Utah).

${ }^{173}$ Haltom \& MCCAnN, supra note 121, at 276 (framing); Neal R. Feigenson, The Rhetoric of Torts: How Advocates Help Jurors Think About Causation, Reasonableness, and Responsibility, 47 HASTINGS L.J. 61, 87-9 (1995).

${ }^{174}$ The frame encompasses the emphasis, presentation of facts, script, theme, ideology, and values. Jorg Matthes \& Matthias Kohring, The Content Analysis of Media Frames: Toward Improving Reliability and Validity, 58 J. CommC'N. 258, 264, 274 (2008).

${ }^{175}$ See Podlas, supra note 3, at 297-302; Kathryn Stanchi, Persuasion: An Annotated Bibliography, 6 J. Ass ${ }^{e}$ N LEGAL Writing DiRECTORS 75, 82 (2009).
} 
encourages the public to conceptualize the issue a certain way. ${ }^{176}$ This foundation of understanding can then impact the way that the public seeks to address the issue. ${ }^{177}$

This also applies to coverage and depiction of legal issues. ${ }^{178}$ The way the media portrays laws, as well as the factual scenarios and morals on which they are justified or to which they apply, shapes perceptions about what laws are, whether they are just, and whether situations warrant legislation. ${ }^{179}$ In turn, this can influence the direction of legal intervention or legislative action. $^{180}$

For example, in the mid-1990s, the media framed product liability lawsuits in terms of greedy plaintiffs with frivolous claims, rather than businesses profiting at the expense of consumer safety. Stories about clumsy coffee drinkers suing McDonald ${ }^{\text {ee }}$ and psychics suing doctors for lost powers proliferated. ${ }^{181}$ Eventually, the public began thinking about personal injury lawsuits in terms of undeserving plaintiffs, out of control juries, and an epidemic of litigation. ${ }^{182}$ The frame then contributed to the publices approval of "tort reforms" that protected businesses and limited damage awards. ${ }^{183}$

\footnotetext{
${ }^{176}$ Kimberlianne Podlas, Testing Television: Studying and Understanding the Impact of Television's Depictions of Law and Justice, LAw And Justice On The Small Screen (Jessica Silbey \& Peter Robeson, eds., 2011); Young Mie Kim \& John Vishak, Just Laugh! You Don't Need to Remember: The Effects of Entertainment Media on Political Information Acquisition and Information Processing in Political Judgment, 58 J. CoMmC'N. 338, 338-42 (2008).

177 Carpenter, supra note 2 at 26-7; HALTOM \& MCCANN, supra note 121, at 275-82.

${ }^{178}$ Podlas, supra note 44, at 22-5.

${ }^{179}$ See HALTOM \& MCCANN, supra note 121, at 19-20.

${ }^{180}$ Kovera, supra note 120, at 62-65; HALTOM \& MCCANN, supra note 121, at 279, 282 (framing of issues defines legislative agenda).

${ }^{181}$ Podlas, supra note 44, at 12 n.61 (articles cited therein); HALTOM \& MCCANN, supra note 121, at 2-6.

${ }^{182}$ Haltom \& MCCANn, supra note 121, at 6-7, 19, 24-5; Feigenson, supra note 173, at 87-9; McCOMBS \& REYNOLDS, supra note 118 , at $10-1$.

183 Another example is the way in which the media frames political candidacies. Where television evaluates political candidates in terms of specific qualities, viewers will also evaluate candidates regarding those same qualities. Michael X. Delli Carpini, Mediating Democratic Engagement: The Impact of Communications on Citizens' Involvement in Political and Civic Life, in Handbook of Political Communication Research 395, 417-21 (Lynda Lee Kaid ed. 2004). Specifically, some studies have shown that where television evaluates political candidates in terms of experience versus change, viewers assess candidates with regard to experience versus change. $I d$.
} 
The nature and effect of framing in the teen sexting epidemic is exemplified by coverage of the child pornography prosecutions. ${ }^{184}$ The wave of coverage about these prosecutions framed teen sexting not only as a legal issue, but as the serious crime of child pornography. Therefore, whereas the amount of coverage devoted to teen sexting made it part of the national conversation, the child pornography frame supplied the language and the conceptual framework within which it was discussed. Further reinforcing the validity of this particular framework was the legal authority of those advancing it. ${ }^{185}$ Moreover, no other frame was presented as an alternative. Considering teen sexting within this framework led to the inescapable conclusion that regardless of whether one believed sexting was prevalent, private, or the digital version of getting to third base, it was a criminal matter that could lead to imprisonment.

\section{LIMITATIONS OF FRAMES}

Frames are helpful in facilitating comprehension and debate by helping people to relate issues to existing knowledge structures, focusing them on a specific issue, or defining the boundaries of debate. ${ }^{186}$ Framing an issue in one way, however, means that it is not framed in another way. Although this is helpful when the frame is accurate and relevant, it can distort issues or obscure alternative approaches when it is not. ${ }^{187}$ This is especially important because once the frame becomes culturally embedded "conventional wisdom," it is seldom re-examined. Thus, a frame has consequences.

\footnotetext{
${ }^{184}$ Halloran McLaughlin, supra note 96, at 138-39 (surge in teen sexting prosecutions).

${ }^{185}$ It was not simply that a legal authority declared that sexting was child porn, but that the media presented this framework for conceptualizing sexting. District Attorney Holds Press Conference on Problem of "Sexting" in Berkshire County, Berkshire Dist. Attorney's Office, http://www.mass.gov/?pageID=bermodulechunk\&L=1\&L0=Home\& sid=Dber\&b=terminalcontent\&f=nu_2009_0303_sexting_press_conference\&csid=Dber (last visited Jan. 5, 2011); Feyerick \& Steffen, supra note 95.

${ }^{186} \mathrm{Kim}$, supra note 176 , at 338-41.

${ }^{187}$ In turn, a misframed or inappropriately framed issue can negatively impact legal or legislative action. The focus may be incorrect, masquerading, or address the wrong thing in the wrong way.
} 
This article suggests that designating child pornography as the frame within which to consider teen sexting and its regulation short-circuited or misdirected debate. Essentially, it infected the cultural knowledge base about sexting. It led the public to believe that teen nudity and the average sext content truly were child pornography, and that prosecution for sext messaging was a real possibility, rather than a rarity. It also altered notions of what was at stake. These understandings became reality. Designating child pornography as the appropriate framework also designated that teen sexting was not about parental supervision, safe sexting, youthful indiscretions, or protecting the privacy of the teens from either a photo $\mathrm{s}$ unintended distribution or a public schoole ${ }^{\text {ee }}$ confiscation and searching of a cell phone. ${ }^{188}$

\section{THE POWER OF STORIES}

Abstract statistics and analytical structures typically do not spark social or legislative epidemics. Rather, their facts and ideas must be memorable or meaningful enough to move people to act. ${ }^{189}$ Communicating them as part of a story ${ }^{190}$ is one way to imbue them with meaning.

Research on the influence of media has shown that, because people think in terms of narratives, ${ }^{191}$ they better remember and are more influenced by news reports in narrative form. ${ }^{192}$ A narrative functions as a conceptual map ${ }^{193}$ that reconfigures information into an intellectually and emotionally accessible form. ${ }^{194}$ A story communicates not only through its literal

\footnotetext{
${ }^{188}$ U.S. CONST. amend. IV.

${ }^{189}$ Gladwell, supra note 2, at 167 (context matters), 139-40 (issues must be relevant).

${ }^{190}$ SHANAHAN \& MORGAN, supra note, at 193 (referencing the power of media stories).

${ }^{191}$ Kimberlianne Podlas, The Tales Television Tells: Understanding the Nomos Through Television, 13 TEX. WESLEYAN L. REV. 31, 34-6 (2006).

${ }^{192}$ Kevin Wise, et al., When Words Collide Online: How Writing Styles and Video Intensity Affect Cognitive Processing of Online News, 53 J. BROAdC. \& Elec. MEdia, 532, 534-35 (2009).

${ }^{193}$ Podlas. supra, note 197, at 34, 36; cf. Lawrence Joseph, The Subject and Object of Law, 67 BROOK. L. REV. 1023, 1030-31 (2002) (law rests on conceptual mapping of what is morally just).

${ }^{194}$ Podlas (Tales), supra, note 191, at 34-36.
} 
explication of facts, but also through its word choice, omission of facts, sequencing of events, and linkage concepts to imply causal relationships. ${ }^{195}$

It can also function as a fable that teaches moral and factual lessons. Therefore, without explicitly declaring what is good or bad, or who is right or wrong, a story can lead the listener to an intended conclusion. ${ }^{196}$ Studies show that audiences often derive greater significance from the moral of a news story than from its facts. ${ }^{197}$

Stories are important in law, because they contextualize abstract legal rules and help explain their real-world application. ${ }^{198}$ They also shape opinions about whether the law should intervene and in what way, ${ }^{199}$ as well as how policies will impact the average person. Because the stories circulated by the media "figure prominently in the cognitive archives from which media-attentive citizens actively construct legal meaning," they matter a great deal. ${ }^{200}$

\section{STORIES OF SEXTING}

The teen sexting epidemic contained two such stories: those about child pornography prosecutions and the sext-related suicide of Jessica Logan. These narratives did not just encapsulate raw information, but they synopsized the issue and what was at stake into a fable with a legal lesson.

In terms of quantitative media coverage, the child pornography and suicide stories together comprised the Spring 2009 spike. As shown in Chart IV, these stories were not

\footnotetext{
${ }_{195}$ See Matthes \& Kohring, supra note 175, at 260-64 (describing methodologies for determining meaning of media content).

${ }^{196}$ Podlas (Tales), supra, note 191, at 36; SHANAHAN \& MoRGAN, supra note, at 193 (memory of narratives often focuses on their lessons rather than on their facts); Yan Bing Zhang \& Jake Harwood, Television Viewing and Perceptions of Traditional Chinese Values Among Chinese College Students, 46 J. BroAd. \& Electronic Media 245, 245 (2002) (television has the ability to communicate the norms, rules, and values of society).

${ }^{197}$ Podlas, supra note 191, at 36; HALtom \& MCCANN, supra note 121, at 274-75.

${ }_{198}$ Podlas, supra note 191, at 35-7.

199 Carpenter, supra note 2, at 26-7; Haltom \& MCCANN, supra note 121, at 11; Timothy E. Lin, Social Norms and Judicial Decision-Making: Examining the Role of Narratives in Same-Sex Adoption Cases, 99 COLuM. L. REV. 739, 759 (1999) (narratives inform judicial decision-making).

200 Haltom \& MCCANN, supra note 121, at 12-13.
} 
concurrent, but consecutive: Skumanick was the front end of the coverage spike and Logan was the back end. Additionally, qualitatively, these stories are distinct. The empirical analysis indicates that coverage referencing the sext-related suicide of Jessica Logan began to emerge in late March 2009 and trailed off in the first week of June 2009. As shown in Chart IV (Relationship Between Coverage of Child Pornography Prosecutions and Coverage of Suicide), the majority of this coverage was the third week of April (April 23-26), just as Skumanick coverage declined. Furthermore, references to Logan were not as much linked to prosecutions, but used to highlight the threat of sexting generally or justify legislative action. ${ }^{201}$

\section{THE MORAL OF THE STORY}

Jessica Logan was a high school senior who sent a naked photo of herself (naked from the neck down) to a boyfriend. ${ }^{202}$ Then as Diane Sawyer summarized it on $\mathrm{ABC}^{\mathrm{ee}} \mathrm{s}$ Good Morning America, "after they broke up, he sent $i^{203}$ to 100 students at four different schools. She was harassed, called names, unrelentingly. The humiliation became too much for her to bear. The eighteen-year-old committed suicide.",204

Logan became a cautionary tale about sexting and proof of the threat of death that sexting posed to adolescents. As Meredith Viera summarized it on $\mathrm{NBC}^{\text {ee }}$ S Today, "Jesse took her own life after a nude photo meant just for her boyfriend was forwarded to others. Her story speaks to

\footnotetext{
${ }^{201}$ As discussed below, despite this linkage, the type of personal harm to the sexter has not been the focus of legislation.

${ }^{202}$ It is unclear whether he was a present or former boyfriend. The court order does not refer to the male student as Logan ${ }^{\text {es }}$ boyfriend. Logan v. Sycamore Cmty. Sch. Bd. Of Educ., 780 F.Supp. 2d 594, 595-96,n.2 (S.D. Ohio 2011); Ostrager, supra note 127, at 120; Mike Celizic, Her Teen Committed Suicide over 'Sexting,' TODAY (Mar. 6, 2009, 9:26 AM), http://today.msnbc.msn.com/id/29546030.

${ }^{203}$ The District Court, ruling on a motion in a lawsuit by Logan"s parents against the school, school personnel, and others, stated "[i]t remains unclear exactly who first transmitted the photo of Logan. The record reflects that Logan herself sent the photo to a male student, while Logan also suspected that some students obtained it from her cell phone" and sent it to others. Logan, 780 F.Supp. at 596 n. 2.

${ }^{204}$ Parental Alert: Sexting; Town Hall Meeting (ABC News transcript Apr. 15, 2009).
} 
the hidden dangers facing today's teens when it comes to technology."205 Thus, in a matter of months, the media coverage of teen sexting had gone from virtually non-existent to warning the public that ",Sextinge could lead to tragic results"206 and "has even resulted in student suicides."207

The Skumanick and Logan narratives were important to the progression of the epidemic. As circulated by the media and recreated as common knowledge, they showed the devastating consequences of teen sexting and the need to do something about it. The former warned that teens could face years of imprisonment as child predators, while the latter demonstrated that the discovery of a sext could lead teens to kill themselves. Together, the moral ${ }^{208}$ was that whether sexting led to imprisonment, denial of educational and vocational opportunities, or severe humiliation, it could ruin a teen's life. ${ }^{209}$

\section{FABLES VS. FACTS}

Three factors are important in understanding the media construction of Logan as a fable and its role in advancing the teen sexting (and subsequent legislative) epidemic.

The first factor is the timing of when the story emerged in the national news as opposed to when the incident occurred. The empirical study reveals that the media did not cover Logan or tell the sexting-can-cause-suicide tale until after the Skumanick spike in coverage, as the issue

\footnotetext{
${ }^{205}$ Inside Your Teen's World; Thomas Grimes and Debra Haffner Discuss Teens and Internet Safety (NBC News transcript Mar. 6, 2009).

${ }^{206}$ Day, supra note 5, at 71.

207 Oluwole, supra note 40, at 58-9; Joe Burns, Teen Sexting Can Have Deadly Consequences, PATRIOT LEDGER (MA), Apr. 3, 2009, at 4; Colleen Carroll Campbell, Sexting Suicides Should Serve As Wakeup Calls, St. Louis DisPATCH, Dec. 10, 2009, at A17; Oluwole, supra note 40, at 58-59; Parents of Dead Teen Sue School, Friends over Sexting Harassment, HuFFINGTON Post, Dec. 7, 2009, available at http://www.huffingtonpost.com/2009/12/07/jessica-logan-suicide-par n 382825.html; U.S. Youth Suicides Linked to "Sexting' but Trend Rises, THE InDEPENDENT, Dec. 4, 2009.

${ }^{208}$ See generally, Joshua Meyrowitz, Power, Pleasure, Patterns: Intersecting Narratives of Media Influence, 58 J. CommC'N 641, 645-47 (2008) (power of narrative in media); Glenn Leshner, et al., When a Fear Appeal Isn't Just A Fear Appeal, 54 J. BROAD. \& ELEC. MEDIA 485, 490-91 (2008) (ability of emotions to increase audience recognition of stories).

${ }^{209}$ Both stories evoked fear. Fear has been shown to increase the persuasiveness of a media message. Leshner, supra note 208, at 486-90.
} 
was germinating. $^{210}$ It seems that just as Skumanick had run its course, the suicide aspect kept the issue alive, and became the epidemices next emergent form.

The problem is that although Logan was first mentioned in early March 2009, she had committed suicide in July of the previous year. ${ }^{211}$ Had the incident independently been consequential or powerful enough to advance the issue, it would have garnered coverage close in time to its occurrence. ${ }^{212}$ To the contrary, it did not become part of the teen sexting epidemic until eight months later. Evidently, restricted to its actual facts, Logan was simply a horribly sad teen suicide, like all teen suicides. Yet when Logan was resurrected, it was in combination with the facts of the sexting contagion. It was no longer merely a sad incident but a reincarnated fable of "sext: humiliation: death." This prolonged the life of the issue of sexting and demonstrated how critical it was to do something about it.

The second factor is this was not a prototypical sexting scenario. Logan was not a minor but an adult when she sent the photo. Therefore, this was not a true teen sexting case; it was an adult sexting a photo of herself and being viciously criticized for it. In fact, Logan se adult status $^{213}$ was the reason why neither the school resources officer ${ }^{214}$ nor the prosecutor pursued legal action; ${ }^{215}$ instead the school officer ordered the accused students to delete and cease sharing the photo. ${ }^{216}$ This additional context recasts the incident as high school bullying or harassment. $^{217}$

\footnotetext{
${ }^{210}$ Celizic, supra note 202; see also Teenage Girl Hanged Herself After Bullying Over 'Sexting,' TeLEGRAPH, Mar. 18, 2009, http://www.telegraph.co.uk/news/worldnews/northamerica/usa/5010361/Teenage-girl-hanged-herself-after-bullying-oversexting.html [hereinafter Girl Hanged Herself]. In fact, the first major news publication to mention Logan was England 'ee The Sun which did so in the context of introducing a cyberbullying initiative. Emily Smith, Suicide Of Sex Txt Pic Jess, 18, THE SuN (England), Mar. 18, 2009, at 29.

${ }^{211}$ Logan, 780 F.Supp. 2d at 595.

${ }^{212}$ For instance, this could have brought attention to teen sexting and been used to agitate public concern and media coverage, or it could have been mentioned at the time of the release of the Cosmogirl survey, but it was not.

${ }^{213}$ Logan, 780 F.Supp. 2d at 596; see also Davis, supra note 150.

214 The School Resource Officer was a City of Montgomery Police Officer. Logan, 780 F.Supp. 2d at 595.

${ }^{215} I d$. at 596, 599..

${ }^{216} I d$.

${ }^{217}$ Logan "es parents also sued (and settled with) the identified students who had allegedly harassed Logan. Id. at 595.
} 
A third factor is the media accounts left a considerable gap between the actual facts and implications of cause and effect. This suicide was undoubtedly a tragedy, but it may not have been a sexting tragedy. Though many sources (including law journal articles ${ }^{218}$ ) state or imply that suicide was a direct result of the sextingee spread, in other words, that the harassment finally became so unbearable that one day Logan returned from school and took her life, ${ }^{219}$ the temporal implication is quite misleading. There were intervening events (and a considerable lapse of time) that are typically omitted from the timeline leading up to the tragedy.

After the school ${ }^{e e}$ s action, Logan contacted and, with her parents blessing, participated in a television interview with a local reporter in which she discussed her sexting incident. ${ }^{220}$ According to Logan ${ }^{e e}$ s parents, it was after this interview that the harassment increased. ${ }^{221}$ Even so, Logan did not kill herself. Rather, in May 2008, she appeared on the Today Show. ${ }^{222}$

It is likely that these actions (and any fallout therefrom) compounded Logan es emotional distress and exacerbated her problems. For instance, publicizing the incident may have made more people aware of it. In fact, any increased harassment may have been due to peer reactions to Logan's behavior. People may have questioned the incongruity between Logan's going public, yet claiming harm because her photo had gone public. Peers may have believed that Logan was parlaying the incident into a means for attention, or they may have resented her for getting the other students in trouble while failing to accept any personal responsibility. ${ }^{223}$

\footnotetext{
${ }^{218}$ Several law journal articles that invoke Jessica Logan also omit these facts. This helps make the point that the mediaes widely-circulated account of Logan, rather than the facts recounted in court documents about it, has become the authoritative version and that this version impacts perceptions and debate about teen sexting.

${ }^{219}$ Ostrager, supra note 127, at 720; "The resulting humiliation and harassment from her peers drove Jesse Logan to hang herself." Hiffa, supra note 24, at 506.

${ }^{220}$ Logan, 780 F.Supp. 2 d at 596-97. Her face was concealed and voice altered. Id. at $595 .$.

${ }^{221} \mathrm{Id}$. at 595 ..

222 See Day, supra note 5, at n. 7.

223 Lindy Kerin, TV Networks' Treatment Of Bullying Story Reprehensible: Carr-Greg, The World Today, ABC NEws (Australia), Mar. 22, 2011, http://www.abc.net.au/worldtoday/content/2011/s3170371.htm (expressing concern that Logan had appeared on television and opining that this type of responsive behavior might normalize it)
} 
Nevertheless, regardless of whether there may have existed other reasons for Logan's situation, she did not kill herself during the school year, but a month after she graduated (during Fourth of July weekend). ${ }^{224}$ Had the in-school harassment been so horrible as to drive Logan to suicide, it would have driven her there months earlier, during the school year, not after high school and when the world supposedly causing her torment had already ended.

This is not intended to diminish this young woman's pain or the tragedy, but to demonstrate how media coverage reincarnated it as a story about the deleterious effects of sext messaging, ${ }^{225}$ which became the dominant narrative for understanding the harms of teen sexting. This informed public and legislative debate ${ }^{226}$ and provided a fertile ground for intervention. Thus the key is not on how the facts were violated, but how the reincarnated "facts" came to be accepted as truth.

\section{THE CURE IS WORSE THAN THE DISEASE}

The accumulation and slant of media coverage also played a role in the recent outbreak of sexting legislation, as well as in the focus on that legislation. Coverage of actual and proposed legislation was the fourth coverage phase identified by the empirical analysis.

\footnotetext{
${ }^{224}$ Logan, 780 F.Supp. 2d at 595.

${ }^{225}$ The moral was both that sexting could have horrible consequences and that people (such as these peers) would think horribly of you if you sexted. The narrative was not presented as a story of parents who were so busy blaming others and putting their daughter in front of television cameras that they failed to appropriately counsel their daughter or notice her mental state. It was not a story about a troubled girl whose humiliation was, literally, by her own hand, who failed to realize her responsibility. Instead, it was about a naïve girl who sent a sext, was castigated with a scarlet "S", and died because of it.

${ }^{226}$ The media has also reported a second (2009) sext-related-suicide. Hope Witsell, who was 13, sexted a topless photo of herself to a boy she liked. When the photo spread throughout the school, the faculty stripped her of her FFA student adviser position and suspended her briefly; Her parents took her cell phone and computer; and she was picked on for months afterward. During that time, Witsell sought help from a school counselor and articulated her desire to kill herself. The school never alerted Witsell's parents. The day before she killed herself, Witsell again expressed this desire, and again, the school did not contact her parents. Instead, the counselor had her sign a "contract" that she would not commit suicide. Witsell went home and hanged herself. Andrew Meacham, Schools Sued in Sexting Death, St. Petersburg Times (Tampa Bay), Apr. 11, 2011, at 1B. Witselles parents are presently suing the school Board for failing to take proper steps upon learning that Witsell showed signs of being suicidal. Thus, this is more accurately an indictment of school administrators who were very aware of Witsellees suicidal intent, but failed to respond sufficiently, than a sext causing suicide. $I d$.
} 
Since October 2009, eighty-three sources of coverage have discussed sext legislation. As shown in Chart III, since December 2009 this coverage has continued at a relatively steady pace.

More importantly, qualitative review reveals that a significant portion of this coverage raised questions about the wisdom of applying child pornography laws to teen sexters. ${ }^{27}$ Specifically, the coverage of prosecutions from November 2008 through June 14, 2009, i.e., to the end of the Spring 2009 coverage epidemic, discloses a negative slant. In analyzing this coverage, the study categorized it broadly as: (a) Negative Toward Prosecution and/or Sympathetic to Teen; (b) Neutral and/or Includes Both Positive and Negative Points of View; (c) Positive Toward Prosecution and/or Negative or Not Sympathetic to Teen. Seventy-eight percent of coverage was Negative Toward the Prosecution (a), just over twenty percent was Neutral (b), and less than one percent was Positive Toward the Prosecution.

Sometimes the negative slant was overt. For -example, opinion/ editorial pieces directly criticized these prosecutions ${ }^{228}$ and the prosecutors responsible for them, ${ }^{229}$ and also asserted that sexting was an issue for parents, not prosecutors.

Other times, the slant was more subtle, evidenced through the narratives told about these cases. They portrayed the teens involved as just regular kids, doing regular, dumb kid things,

\footnotetext{
${ }^{227}$ Arcabascio, supra note 9, at 91 ; Brown, supra note 170, at 11A (issue is subject to debate and has prompted legislative change across country); Calvert, supra note 28, at 1, 6-7; Day, supra note 5, at 71-72; Prieto (Mar. 8), supra note 95; Sherman, supra note 15, at 142 (laws that were not drafted to cover this situation); McElroy, supra note 4, at 10, 11; (legal system is struggling with how to treat sexting); Wastler, supra note 23, at 688-89.

${ }_{228}$ Bazelon, supra note 19; Ahmina James, Making Sexting a Crime Sends Wrong Message to Teenagers, S.F. CHRON., Mar. 22, 2009, at H-3, available at http://www.sfgate.com/cgi-bin/article.cgi?=/c/a/2009/03/22/IN5j16IIoI.DTL; Editorial, 'Sexting' Overkill, Philadelphia Inquirer, Apr. 6, 2009, at A10; Editorial, Teens' Stupid Conduct Is For Their Parents To Address, Not The DA, Beaver Co. Times (PA), Apr. 2, 2009, Sally Kalson, Editorial, Sexting ... And Other Stupid Teen Tricks; What's Stupider, Though, Are Adults Who Criminalize Youthful Indiscretions, PitTsBURGH Post-GaZette, March 29, 2009 at G3, http://www.post-gazette.com/pg/09088/958821-149.stm; XXXtra Discretion is Advised, supra note 95, at 10A.

${ }_{229}$ Marcus, supra note 93, at A21; Prosecutors Gone Wild, supra note 7 (asserting this should be handled by parents, and criticizing prosecutions); Louis (Apr. 23), supra note 7, at 31 ("We need to put a leash on rigid-minded prosecutors who, it seems, can "t resist bringing the weight of the law down on youngsters who don"t act right"); Louis (Apr. 22); Casey, supra note 7; Bazelon, supra note 19 (asserting that $3^{\text {rd }}$ Circuit could have gone further in rejecting Skumanickes treating sexting as potential child porn"); Kinney, supra note 7; Youthful Mistake, at 2P (such youthful indiscretions should be teachable moments about privacy and restraint rather than life-altering criminal actions); Rubin, supra note 7, at B 01 (criticizing prosecutions).
} 
who clearly did not fit society ${ }^{\text {ee }}$ n notion of a child predator. ${ }^{230}$ These stories included facts sympathetic to the teens, specifically that the sext messaging was consensual or exchanged in a relationship (or spread after a break-up) and highlighted the disproportionate harshness of the penalties. $^{231}$ By contrast, coverage did not applaud prosecutors for their actions or explain that they were preventing sexting or protecting innocent teens. Some stories even included quotes from prosecutors that their hands were tied. ${ }^{232}$

The overall message was that prosecuting teens as a "cure" for teen sexting was worse than the disease. Therefore, while adults first may have feared that adolescents would be infected by the sexting trend, they now had to worry that their children could be imprisoned as child pornographers.

Consistent with this message ${ }^{233}$ and social science research that the inclusion and structuring of elements in news commentary can impact public perceptions of issues, ${ }^{234}$ the public and lawmakers began to condemn these prosecutions. ${ }^{235}$ Indeed, a media-defined crisis of this sort is not a neutral recognition of a fact or a situation--it is a political act. ${ }^{236}$ The designation of a crisis refocuses the public agenda to the issue, and demands that something be done about it. ${ }^{237}$ Here, the progression of coverage, from the prevalence of sexting, to

\footnotetext{
${ }^{230}$ Pawloski, supra note 19, at A 004; Bazelon, supra note 19 (describing context and gender); Brown, supra note 170.

231 Brown, supra note 170, at 11A (DA says only option is to prosecute under child pornography and obscenity statutes); Rowland, supra note 3, at B 01; see also Kowalczyk, supra note 23, at 686-87 (prosecutions controversial); McElroy, supra note 4, at 10, 16 (punishment too severe); Sherman, supra note 13, at 142; Wastler, supra note 23, at 117.

232 Brown, supra note 170, at 11A; Investigation into Junior High Naked Photo Exchange Growing, DESERET MORNING NEWS (Utah), Apr. 1, 2008 (quoting County Attorney, "even if it" s consensual, such pictures are legally child pornography"); Joyce, supra note 20 (York County prosecutor stating that "nude photos of minors, consensual or not are treated as child pornography").

${ }^{233}$ Podlas, supra note 44, at 11; Mike Celezic, Vermont Moves to Reduce Teen 'Sexting' Charges, MSNBC, Apr. 15, 2009, http://www.msnbc.msn.com/id/30224261. Entertainment media also plays a role in educating the public about law. For example, in one episode of Law and Order: Special Victims Unit, Crush, a teenager is brutally beaten in connection with a nude photo that she had text messaged to peers, and then is charged with child pornography. Law and Order: Special Victims Unit, Crush (NBC television broadcast May 5, 2009)

${ }^{234}$ HALTOM \& MCCANN, supra note 121, at 276-78.

${ }^{235}$ Arcabascio, supra note 9, at 9 3; Galanos, supra note 95; Levine, supra note 173. Although the criminal justice system exerts power as an authority, when people do not respect a legal authority or its decisions, that powere dissipates. Podlas, supra note 3 , at 293-94.

${ }^{236}$ Podlas, supra note 3 , at 281-82.

${ }^{237}$ Id. at $282-83$.
} 
prosecutions, to its consequences, laid a foundation for lawmakers to understand teen sexting as a "legislation-worthy" issue. It also, however, identified a single, particular problem to be solved -- the penalties of child pornography convictions.

\section{LEGISLATIVE OUTBREAK}

Just as teen sexting and the concept of the teen sexting epidemic spread like a virus, so can, and did, legislation about sexting. Applying Gladwelle's thesis that ideas spread and mutate like viruses, culminating in epidemics, Carpenter asserts that a social trend or perception of an epidemic can erupt into a "legislative epidemic."238 Essentially, hoping to address or cure an emerging social concern, policymakers may rush to legislate or get caught up in the fever of a legislative trend. This leads to a legislative outbreak. ${ }^{239}$ Unfortunately, opting for speed over logical review of an issue ${ }^{240}$ can worsen the underlying problem, ${ }^{241}$ if there even is one, create a new one, or result in needless legislation.

The recent outbreak of sexting legislation exemplifies the concept of a legislative epidemic. According to the National Center for State Legislation, in 2008, no states had considered sexting legislation, ${ }^{242}$ not even Ohio, the home of Jessica Logan. By the end of 2011, however, seventeen states had enacted sexting laws or revised their child pornography (or related) statutes. ${ }^{243}$ Notably, during this period of time, media coverage of legislation continued at a steady pace.

\footnotetext{
${ }^{238}$ Carpenter, supra note 2, at 2-4 6-10.

${ }^{239} I d$. at 10.

${ }^{240}$ See Walters, supra note 10 , at 98.

${ }^{241} \mathrm{Id}$. at 98-99.

$242 \quad$ Stateline.org, 2008 state-by-state summary (last updated Oct. 24, 2008) http://www.stateline.org/live/details/story?contentId=322840\#OH (Stateline.orges state-by-state rundown of significant legislative action in 2008).

243 See Nate 1 Conference of State Legislatures, 2009 Legislation Related to Sexting (Sept. 1, 2010), http://www.ncsl.org/default.aspx?tabid=17756; Nat'1 Conference of State Legislatures, 2010 Legislation Related to Sexting (Jan.
} 


\section{IN SEARCH OF A CURE}

Though the media helped set the stage for legislative action, legislation could have taken many forms and tackled a variety of issues. For example, legislation could have expanded privacy rights to allow a sexter to pursue a tort claim; $;{ }^{244}$ revised statutes to exclude sexting from the ambit of child pornography; funded programs or required educational institutions and public service agencies to educate teens about safe sexting; categorized the consensual creation and viewing of such media as private; or clarified the circumstances under which public schools could confiscate and search students" phones. Instead, lawmakers by and large followed the path forged by the media coverage regarding the inappropriate severity of child pornography convictions. Apparently, the media did such a good job of publicizing the maladies of child porn prosecutions that legislators focused on correcting that problem to the exclusion of any others. ${ }^{245}$ It thus appears that while the media helped prompt legislation, its coverage may have preempted policy debate on alternative approaches to teen sexting. ${ }^{246}$

Most legislation undertaken to address sexting endeavors is designed to rescue teens from the harsh penalties of a child pornography conviction. The means to achieve this vary. Some states divert teens out of the criminal justice system into juvenile (or similar adjudicatory) courts or give prosecutors discretion to do so. ${ }^{247}$ For example, New Jersey and Vermont created

\footnotetext{
4, 2011), http://www.ncsl.org/default.aspx?tabid=19696; Nat" 1 Conference of State Legislatures, 2011 Legislation Related to Sexting (Sept. 2, 2011), http://www.ncsl.org/default.aspx?tabid=22127.

${ }^{244}$ Eraker, supra note 35, at 594-95 (suggesting that civil remedies for violation of privacy and infliction of emotional distress might be most appropriate for sext- bullying).

${ }^{245}$ See HALTOM \& MCCANN, supra note 121, at 282-83 (when the media focuses legislative attention on one issue, it effectively diverts attention from other issues).

${ }^{246}$ As a new issue of technology, implicating changing norms within a new social environment, sexting begged for new policy and legislation (which, in turn, could have established a rational foundation for future related issues), rather than being shoehorned into decades-old child pornography laws that most people agreed were inapt. That a few prosecutors had gone overboard did not need to restrict legislative action. States believing that sexting should be prevented could have started by considering a broader array of approaches, and devoted their energy to crafting new laws, rather than tinkering with old child pornography laws written for an entirely different situation.

${ }^{247}$ Some scholars argue that sexting or child pornography laws should permit prosecutorial discretion in determining whether a particular case warrants prosecution and at what level. Sherman, supra note 15, at 157 ("permitting prosecutorial discretion prevents teenagers from being excessively punished for engaging in what they may consider flirting"). This ignores that
} 
diversionary programs for minors who sext. Vermont, which is often cited as an exemplar of sexting legislation, ${ }^{248}$ funnels minors with no prior offenses into juvenile court, ${ }^{249}$ but prosecutes subsequent sexting offenses as sexual exploitation of a child. ${ }^{250}$

Other states amended their child pornography statutes to reduce the crime, if committed by a minor, from a felony to a misdemeanor offense. ${ }^{251}$ Texas, Utah, Arizona, Missouri, and North Dakota have followed this course. For example, in Utah, prosecutors have discretion to reduce felony "dealing in harmful material to a minor" charges to a misdemeanor. ${ }^{252}$ Some states reduce the penalties a teen faces. Louisiana, for instance, exempts individuals nineteen and under from registering as a sex offender. ${ }^{253}$ Others, such as Nebraska and Arizona, provide affirmative defenses that either preclude prosecution of a minor and/ or place those acts into a different category (thereby avoiding a child pornography conviction). ${ }^{254}$ Nebraska provides an affirmative defense for a self-produced visual depiction, if it includes only the defendant, and he is under nineteen and the minor in the visual depiction is at least fifteen. ${ }^{255}$

prosecutors almost always have some degree of discretion and that Skumanick and several similar cases were the product of prosecutorial discretion. Others advocate juvenile court adjudication or similar downward diversion. Again, this is at the option of the prosecutor, and, therefore, again, this suffers from the same flaw.

${ }^{248}$ Sherman, supra note 15 , at 147.

${ }^{249}$ See Vt. Stat. AnN. tit. 13, § 2802b(b) (2009); The Vexing Issue of "Sexting”, Nat'l Conf. of St. Legislatures (July/Aug. 2009), available at http://www.ncsl.org/default.aspx?tabid=18006; Don Corbett, Let's Talk About Sext: The Challenge of Finding the Right Legal Response to the Teenage Practice of "Sexting," 13 No. 6 J. INTERNET L. 3, 6 (2009). This option is available only if the teen can show that the sexting was consensual and between parties within the ages of thirteen and eighteen and does not apply to downstream sexting. Wastler, supra note 23, at 118.

${ }^{250}$ Tit. $13, \S 2802 \mathrm{~b}(\mathrm{~b})(3)$.

${ }^{251}$ Brown, supra note 170 , at $11 \mathrm{~A}$.

${ }^{252}$ Day, supra note 5, at 76-7; Fulton, supra note 1.

${ }^{253}$ Sherman, supra note 15, at 157-58. Since 1994, federal law has required States, as a condition for the receipt of certain law enforcement funds, to comply with federal sex-offender registration and community notification schemes. In order to make these state schemes more comprehensive and uniform, in 2006 Congress enacted the Sex Offender Registration and Notification Act (SORNA or Act) as part of the Adam Walsh Child Protection and Safety Act, Pub. L. No. 109-248, tit. 1, 120 Stat. 590 (2006).

${ }^{254}$ Some academics argue that such exceptions include age proximity requirements and age-range cutoffs. Sherman, supra note 15 , at $155-56$.

${ }^{255}$ Pursuant to NeB. Rev. StAT. § 28-813.01(3)(a) (2009), the defendant may interpose an affirmative defense, if the visual depiction portrays no person other than the defendant, but the defendant must be under nineteen and the minor in the depiction must be at least fifteen, it must be produced and distributed by that minor, and include only that minor. $\S 28-813.01(3)(b)$. Thus, a minor (under nineteen) who texts a photo "available" to another would not be entitled to this affirmative defense. Arcabascio, supra note 9, at 67 . Nor would a "minor who receives a sexually explicit photo, knowingly generated by someone fifteen years of age or older and voluntarily sent without coercion by the defendant, that contains more than one child". Id. 
A handful of states, however, including Colorado, Connecticut, Florida, Illinois, Louisiana, Oregon, and Texas, have created new sexting-specific statutes. ${ }^{256}$ North Dakota, for instance, created a sext crime criminalizing the electronic dissemination of "a photograph or visual representation that exhibits a nude or partially denuded human figure,"257 and Florida created the offense of "sexting."

These legislative efforts are more obviously linked to media coverage than founded on the theories popularizing law journal articles. Although several academics criticize child pornography penalties as too severe, academic debate revolves around whether a teen's selfproduced, self-distributed sext amounts to child pornography (since it lacks the circumstances of production, harm, and underlying criminal element that justified the laws in Ferber and Osborne). ${ }^{258}$ Unfortunately, no matter how insightful, academic debate often registers at a frequency that only academics can hear. ${ }^{259}$ As a result, it can be irrelevant in the public sphere and/or be unable to shape the inaugural legislative policy. ${ }^{260}$

In fact, when the content of these laws is analyzed, virtually all respond to either the Skumanick or Logan situations, i.e., they either seek to prevent the ramifications of a child pornography conviction by amending the child pornography law ${ }^{261}$ or to deter sexting and its

\footnotetext{
${ }^{256}$ Kowalczyk, supra note 23, at 706-08; Parrilla, supra note 18, at A1 ("several states have passed new sexting laws"); Sherman, supra note 15, at 154-55. The dates of this legislation are: Colorado (2009), Connecticut (2010), Florida (2011), Illinois (2010), Louisiana (2010), Oregon (2009), and Texas (2011).

${ }^{257}$ N.D. CENT. CODE $\S 12.1-27.1-01(13)$ (2009). This statute requires intent: "[a] person is guilty of a class A misdemeanor if, knowing of its character and content," he or she "[d]istributes or publishes, electronically or otherwise, a sexually expressive image with the intent to cause emotional harm or humiliation to any individual depicted in the sexually expressive image." $\S$ 12.1-27.1-03.3(1)(b).

${ }^{258}$ See e.g., Humbach, supra note 32 , at 439.

${ }^{259}$ This author acknowledges the irony of asserting this in an academic article.

${ }^{260}$ Scholarship might impact jurisprudential thought and thus the law as applied, or provide a foundation for attacking enacted laws, but when it gets into the game late, cannot impact the beginning stages. In the case of teen sexting, those initial stages include whether the issue constitutes a matter to be addressed by the legal system, if so how, and whether it requires legislative intervention.

${ }^{261}$ In its synopsis of legislation, Nevada stated " $[\mathrm{t}]$ he rapid advancement of new technology, such as cell phones with cameras, has created the unintended consequence of making it easy for children to violate these child pornography laws." 2011 Nev. Stat. 245.
} 
harms ${ }^{262}$ by placing the act into a new statute criminalizing that speech. Laws such as Nevadaes and Vermontes appear to be inspired by the narrative of a prototypical, innocent teen-sexting scenario. Their respective specificity, however, may make them so narrow that they fail to cover and protect a majority of actual teen sexters. ${ }^{263}$ The empirical analysis disclosed that mentions of Logan or suicide commonly appear in coverage of sexting legislation. Sexting suicides, however, are factually inapt to criminal child pornography laws. Criminal law punishes the sexter and attempts to deter sexting; the suicide fable recasts the sexter as a victim, victimized by the sext"s spread. Nonetheless, its emotional impact and moral is that teen sexting is bad, can have horrible consequences, and something needs to be done about it. Legislation, thus, is that something.

The only laws that do not follow the established narrative are those that address sexting through alternative approaches, such as education, ${ }^{264}$ or were not passed. With regard to the former, New York, California, Virginia, and Indiana also opted to study the issue or educate adolescents and their parents. With regard to the latter, after officials and parents voiced concerns that teen sexters could be charged with felonies, New Hampshire formed a legislative subcommittee to study the issue. Ultimately, the committee recognized that sexting may be a developing problem, but determined that it did not warrant legislation ${ }^{265}$ since no New Hampshire teen had been prosecuted for sexting. ${ }^{266}$

\footnotetext{
${ }^{262}$ Some people advocate sexting regulation as a means to protect the sexter from humiliation due to the spread of a sext, in other words, to prevent Logan. No recent legislation has explored this not tort theory. Rather, they are criminal statutes or amendments thereto focused on deterring the creation and sharing of the photo by punishing the sexter. Those laws would not have helped Logan, unless they caused her to never sext in the first place. They might, however, further harm an alreadyhumiliated sexter by adding a criminal prosecution to the embarrassment of a sextes spread.

${ }^{263}$ For instance, they do not seem to consider the natural distribution of a sext or the risk to a passive recipient. A passive recipient who merely receives and opens a text, not knowing its content, might not be protected by these laws.

${ }^{264}$ New York, Indiana, and California have chosen to study the issue and promote education. New Jersey seemed to take every approach - education (via schools and cell phone providers), diversionary programs, and sext statutes - thereby diminishing each of them.

${ }^{265}$ Sherman, supra note 15, at 148 (citing 'Sexting' Not on the Agenda; Teenagers Rarely Charged for Photos, CoNCORD MONITOR, Sept. 11, 2009.

${ }^{266} I d$.
} 


\section{SIDE EFFECTS OF LEGISLATION}

When contrasted against a child pornography conviction and its lifelong consequences, these defenses, reduced penalties, alternative adjudication schemes, and sexting statutes seem preferable. Yet, the fact that these may be preferable does not make these new sexting-specific laws sound or constitutional. It only makes them the lesser evil. ${ }^{267}$

A number of statutes criminalizing teen sexting or providing similarly operative defenses create a new category of illegal sexting, thereby pre-empting (either in practice or by law) the application of child pornography laws. Several scholars, however, assert that using the child pornography frame in the first place is not only analytically incorrect but also unconstitutional. They argue that self-produced pornography, even if by or of hot teens, does not qualify as "child pornography." ${ }^{268}$ Hence, employing the child pornography frame, even if the resulting sexting law provides for a more lenient penalty, entrenches a questionable legal theory and disregards consideration of equally valid, alternative approaches. The effect of these new sext laws would be to either give Skumanick a whole new statute under which to prosecute girls in bras or enable him to use the existing child pornography statute and skip the step of proving that the content of the photo actually met the legal definition of child pornography.

These statutes improve a teen"s situation only if the speech encompassed in a sext does indeed amount to illegal child pornography; it is only in that situation that the minor faces a child porn conviction. If the sext content does not truly rise to this level, then there is no crime or potential conviction to be avoided. The new category therefore, would criminalize speech that was not previously illegal. ${ }^{269}$ In other words, these statutes do not carve out an exception to the application of a child pornography statute, but carve out the type of speech (based on age and

\footnotetext{
${ }^{267}$ McElroy, supra note 4, at 16 (legislative responses are proving equally defective).

${ }^{268}$ United States v. Gleich, 397 F.3d 608, 614 (8th Cir. 2005) (buttocks do not constitute part of the genital or pubic region).

${ }^{269}$ They simply create a new category of illegality, albeit a lesser one.
} 
method of transmission, hence a sext message) and then make it an entirely new crime. Consequently, statutes that criminalize sext messages, even as a lesser offense, might unconstitutionally restrict the speech of minors.

It should go without saying that only images that meet the legal definition of child pornography can be prosecuted as child pornography or trigger prosecutorial discretion regarding whether to prosecute. But if the recent legislation is any indication the point bears repeating. Not all sexted images constitute child pornography; ${ }^{270}$ in fact, most probably do not.

Generally, to constitute child pornography, ${ }^{271}$ the work must depict sexually explicit conduct, which is defined to include the "lascivious exhibition of the genitals or pubic area of any person."272 The United States Code defines "sexually explicit conduct" as "sexual intercourse, including genital-genital, oral-genital, anal-genital, or oral-anal, whether between persons of the same or opposite sex; bestiality; masturbation; sadistic or masochistic abuse; or lascivious exhibition of genitals or pubic area of any person." ${ }^{273}$ Even when hot teens are involved, nudity does not amount to illegal child pornography. ${ }^{274}$ "[D]epictions of nudity,

\footnotetext{
${ }^{270}$ Kowalczyk, supra note 23, at 700 (not all sexting fits within child pornography); Wastler, supra note 23 , at 109 (activity recorded in text may be entirely legal); see also W. Jesse Weins \& Todd C. Hiestand, Sexting, Statutes, and Saved by the Bell: Introducing a Lesser Juvenile Charge with an "Aggravating Factors" Framework, 77 TENN. L. ReV. 1, 26 (2009) (sexting must amount to child pornography).

${ }^{271}$ The Supreme Court has found constitutional the child pornography statutes in Ferber and Osborne, and ruled on aspects of the federal statute, therefore these help delineate the constitutional contours and basic definition of child pornography. Additionally, many states have adopted the language of and sought to criminalize the same category of behavior as these laws. See United States v. Nemuras, 567 F. Supp. 87 (D. Md. 1983), aff'd, 740 F.2d 286 (4th Cir. 1984) (interpreting "lewd" exhibition and "lascivious" exhibition as interchangeable).

27218 U.S.C. $\$ 2256(2)(\mathrm{A})(\mathrm{v})(2006)$.

27318 U.S.C. $\$ 2256(2)(A)$. Ferber prohibited "lewd exhibitions of the genitals" (in the context of sexual conduct) and Osborne prohibited the "performance of a minor who is in a state of nudity, where such nudity constitutes a lewd exhibition or involves a graphic focus on the genitals. State v. Young, 525 N.E. 2d 1363, 1368 (1988). Responding to the dissent se concern that the statute was overbroad, the Supreme Court clarified that "The crucial question is whether the depiction is lewd, not whether the depiction happens to focus on the genitals or the buttocks. Id. at 1373. "In any event, however, Osborne would not be entitled to relief. The context of the opinion indicates that the Ohio Supreme Court believed that "the term 'nudity' as used in R.C. 2907.323(A)(3) refers to a lewd exhibition of the genitals" Id.

${ }^{274}$ In Osborne, the Supreme Court noted "We have stated that depictions of nudity, without more, constitute protected expression. Osborne v. Ohio, 495 U.S. 103, 112 (1990); See Ferber, 458 U.S. at 765, n. 18; Jacobson v. United States, 503 U.S. 540, 542-43 (1992) (Defendant received magazines entitled Bare Boys I /II which contained photographs of nude preteen and teen boys, but the boys were not engaged in sexual activity. Consequently, this was not lascivious exhibition, and, therefore, not child pornography).
} 
without more, constitutes protected expression." 275 Therefore, without delving into legal theory, sext laws, that at their heart, criminalize depictions of teen nudity or some version thereof are unconstitutional.

Aside from the highly nuanced legal issue of whether a sext message ${ }^{\text {ee }}$ s different means of production, lack of underlying criminal act, and absence of victimization in its creation distinguishes teen sext messages from child porn, ${ }^{276}$ there is a more basic issue with a simpler answer: Do teen sexts meet the facial (statutory) definition of child pornography? To the extent that these sext laws regulate sext messages that do not rise to the level of sexually explicit behavior or lascivious exhibition of the genitals, ${ }^{277}$ they are presumably unconstitutional. ${ }^{278}$ Speech that is not obscene cannot be suppressed to protect minors from ideas or images that the government thinks unsuitable for them. ${ }^{279}$ As the Court reiterated last term, minors are entitled to a significant measure of First Amendment protection; therefore, the government can ban speech to minors only in relatively narrow and well-defined circumstances. ${ }^{280}$ Although most academic debate has focused on these First Amendment implications, the recent decisions by the Third Circuit and Pennsylvania district court highlight that sext legislation or prosecutions may

\footnotetext{
${ }^{275}$ Humbach, supra note 32, at 456, Osborne, 495 U.S. at 112 (1990) (citing Ferber, 458 U.S. at 765, n.18). In Erznoik v. City of Jacksonville, 422 U.S. 205, 213 (1975), the Court invalidated a statute that "would [have] bar[red] a film containing a picture of a baby's buttocks, the nude body of a war victim, or scenes from a culture in which nudity is indigenous. The ordinance also might [have] prohibit[ed] newsreel scenes of the opening of an art exhibit as well as shots of bathers on a beach."

${ }^{276}$ To date, the handful of academic articles on sexting have focused on its first Amendment implications, i.e., whether pornography made and shared by minors constitutes the category of child pornography that can be regulated (is illegal) and, if it is, whether the criminal justice system should treat it differently because of its inherent differences. Relatively few delve into the practical, real-world issue of whether the content of the average teen sext message - notwithstanding its means of production, underlying criminal act, and degree of victimization- meets the statutory requirement of being a depiction of sexually explicit conduct.

${ }^{277}$ Skumanickees logic seemed to be that the act of being naked to some degree, or sending a photo of it, was sexual and because it was a teen who naked, it was explicit.

${ }^{278}$ They violating the minores First Amendment rights, not to mention the parent"s Fourteenth Amendment rights to determine the upbringing of their children.

279 Brown v. Entm't Merchs. Ass'n, 131 S. Ct. 2729, 2736 (2011) (citing Erznoznik v. City of Jacksonville, 422 U.S. 205, 213-14 (1975)).

${ }^{280} I d$.
}

PGH. J. TeCh. L. \& POL ${ }^{e} Y$, Vol. 12, No. 1, Fall 2011 
infringe on a parent ${ }^{e s}$ Fourteenth Amendment rights. ${ }^{281}$ Interestingly, though the parental rights idea has not been advanced by legal academics, it has been articulated by the media as a matter of common sense, if not legal theory. It is likely that this theory will figure prominently in the next cycle of litigation, legislation, and media coverage.

\section{CONCLUSION}

The media plays a complex and important role in the cultural production of knowledge. The stories told, "facts" circulated, and cognitive frameworks employed by the media become the premises and analytic foundations that inform the publices understandings of law and undergird legal and legislative action. ${ }^{282}$ In this way, the media impacts legislation. ${ }^{283}$

The analyses here suggest that the media played such a role in the progression of the teen sexting epidemic from an initially-ignored, questionable statistic to a legislative trend. Indeed, a critical principle of virology is that the strain of a virus circulating at the onset of an outbreak is not the same strain circulating at its end. Instead, as it interacts with other social or infectious agents, it mutates or transforms. Here, it transformed into legislation. As noted, the majority of that legislation either reduces criminal penalties for teen sexting or criminalizes it anew. It does not enact the view that teen sexting is a personal or parental issue, rather than a legal one. Of course, states embracing this view may have rejected any proposed legislation. Nonetheless, it is not clear that the legal issue of teen sexting has run its course; rather, it may soon re-emerge as a new strain with a new legislative focus.

\footnotetext{
${ }^{281}$ The Due Process Clause of the Fourteenth Amendment protects the fundamental right of parents to make decisions concerning the care, custody, and control of their children. Troxel v. Granville, 530 U.S. 57, 65-66 (2000); Stanley v. Illinois, 405 U.S. 645 , 651 (1972); Pierce v. Society of Sisters, 268 U.S. 510, 534-35 (1925); Meyer v. Nebraska, 262 U.S. 390, 399, 401 (1923).

${ }^{282}$ This can also be in the form of criticisms of laws, belief that law is just, or adherence to its authority. Kimberlianne Podlas, "I'm a Politician, But I Don't Play One on TV": Applying the Equal Time Rule (Equally) to Actors-Turned-Candidates, 20 Fordham InTELl. Prop. MEdia \& ENT. L.J. 165 (2009).

${ }^{283}$ HALTOM \& MCCANN, supra note 121 , at 267.
} 